\title{
Share Repurchases as a Tool to Mislead Investors: Evidence from Earnings Quality and Stock Performance ${ }^{1}$
}

\author{
Konan Chan ${ }^{\mathrm{a}, \mathrm{b}}$, David Ikenberry, ${ }^{\mathrm{c},}$, Inmoo Lee ${ }^{\mathrm{d}}$, and Yanzhi Wang ${ }^{\mathrm{a}}$ \\ ${ }^{a}$ Department of Finance, National Taiwan University, Taipei 106, Taiwan \\ ${ }^{\mathrm{b}}$ School of Economics and Finance, University of Hong Kong, Hong Kong \\ ${ }^{\mathrm{c}}$ Department of Finance, University of Illinois at Urbana-Champaign, Champaign, Illinois 61821, USA \\ ${ }^{\mathrm{d}}$ National University of Singapore, Singapore 117592
}

September 2005

\begin{abstract}
Several studies find that share repurchases are associated with positive wealth effects, both in the shortand long-run. By the same token, the credibility of buyback announcements as quality signals, particularly those to be executed on the open market, has been questioned. In this paper, we consider whether a sub-set of repurchase programs are perhaps motivated by an intent to mislead the market. Although intentions are not observable, we indirectly accomplish this by separating firms by their earnings quality. Firms which aggressively employ discretionary accruals, particularly those which also show lagging stock price performance, exhibit traits which suggest that executives may have been under pressure to boost stock prices. In the short-term, these programs are effectual as the market does not appear to initially distinguish firms on the basis of earnings quality. Over longer horizons, firms with poor earnings quality suffer from poor operating performance and tend to repurchase relatively fewer shares. More importantly, unlike the positive return drift generally observed after a repurchase announcement, long-horizon stock performance for poor earnings quality firms is not significant. The evidence is consistent with the notion that in some cases, company executives may be using repurchase programs to manipulate market opinion. The fact that some buyback programs, ex-ante, may be manipulative in intent provides some insight into why market underreaction is often observed in the empirical literature. The evidence here provides some justification for investor skepticism when open market buyback programs are initially announced.
\end{abstract}

JEL classification: G10; G30; M40

Keywords: Share repurchases; Earnings quality; Discretionary accruals; Price manipulation

\footnotetext{
* Corresponding author. Tel.:217/333-6396; Fax:217/333-4101; e-mail: daveike@uiuc.edu

${ }^{1}$ Chan acknowledges financial support from the National Science Council of Taiwan (NSC92-2416-H-002-049EF). Lee acknowledges financial support from the National University of Singapore. We acknowledge useful comments from Sheng-Syan Chen, Yehning Chen, Joseph Fan, Shing-Yang Hu, T.J. Wong, and the seminar participants at Chinese University of Hong Kong, Concordia University, National Taiwan University, National University of Singapore and the University of Hong Kong.
} 


\title{
Share Repurchases as a Tool to Mislead Investors:
}

\author{
Evidence from Earnings Quality and Stock Performance
}

\begin{abstract}
Several studies find that share repurchases are associated with positive wealth effects, both in the shortand long-run. By the same token, the credibility of buyback announcements as quality signals, particularly those to be executed on the open market, has been questioned. In this paper, we consider whether a sub-set of repurchase programs are perhaps motivated by an intent to mislead the market. Although intentions are not observable, we indirectly accomplish this by separating firms by their earnings quality. Firms which aggressively employ discretionary accruals, particularly those which also show lagging stock price performance, exhibit traits which suggest that executives may have been under pressure to boost stock prices. In the short-term, these programs are effectual as the market does not appear to initially distinguish firms on the basis of earnings quality. Over longer horizons, firms with poor earnings quality suffer from poor operating performance and tend to repurchase relatively fewer shares. More importantly, unlike the positive return drift generally observed after a repurchase announcement, long-horizon stock performance for poor earnings quality firms is not significant. The evidence is consistent with the notion that in some cases, company executives may be using repurchase programs to manipulate market opinion. The fact that some buyback programs, ex-ante, may be manipulative in intent provides some insight into why market underreaction is often observed in the empirical literature. The evidence here provides some justification for investor skepticism when open market buyback programs are initially announced.
\end{abstract}




\section{Introduction}

In recent decades, share repurchases have gained popularity throughout the world. ${ }^{1}$ A long literature argues that firms buy back stock for a variety of reasons, reasons which are generally characterized as beneficial to both shareholders and the economy. One such key motivation is that buybacks are a mechanism by which managers can respond to perceived mispricing in the stock market. This view of buybacks in a signaling context is not only supported in surveys of chief financial officers (see for example, Brav, Graham, Harvey, and Michaely (2005)) but also in numerous academic studies (two recent studies include Grullon and Michaely (2004) and Chan, Ikenberry and Lee (2004)). Of course, other value-enhancing factors also appear to motivate why companies choose to repurchase stock. $^{2}$ Taken together, these stories generally paint a positive image of share repurchases. ${ }^{3}$ The empirical evidence is clearly consistent with this view. ${ }^{4}$ In the short-run, the average initial market response to program announcements is positive. In the long-run, there is evidence of long-horizon return drifts. Recently, Chan, Ikenberry and Lee (2004) find evidence of positive earnings surprises after buyback announcements.

Yet while an extensive literature portrays a favorable view of the economic role of repurchases, some surveys of corporate executives suggest an unexplored, alternative motivation. Specifically, one reason that firms may announce a buyback program may be to mislead investors and, perhaps, in an indirect way, manipulate stock prices. For example, in 1998, Institutional Investor reported survey results of CFOs as to why they repurchase stock. Among the various choices was the category "to support the stock." Given that outright manipulation is largely frowned upon by the SEC rule 10b-18, the fact that this

\footnotetext{
${ }^{1}$ Grullon and Michaely (2002) report that from 1983-2000, spending by U.S. firms on share repurchases grew at a rate of about $20 \%$ per year. This contrasts with the comparable growth rate in dividends of only $6 \%$. Compared to initial public offerings, aggregate repurchases over this period were nearly three times greater than the proceeds raised through IPOs.

${ }^{2}$ For example, buybacks are well-known to be a tax-efficient vehicle to return free cash flow to shareholders. Grullon and Michaely (2002) report that during the 1990s some companies began using buybacks as a form of dividend substitution. Repurchases known as green-mail have also been used to defend against hostile takeovers. Repurchases are, by definition, a tool for managing capital structure and thus are a means for addressing accumulated earnings that otherwise disturb target debt-equity ratios or to reverse the equity-expanding dilution caused by the exercise of employee stock options (Jolls (1998), Fenn and Liang (2001) and Weisbenner (2000)). Dittmar (2000) summarizes these motivations and points out that a blending of motivations may be at work in any one case. Grullon and Ikenberry (2000) also comment in greater detail as to why firms repurchase stock.

${ }^{3}$ One might argue that an exception to this positive generalization exists in the market-microstructure literature, beginning with the work of Barclay and Smith (1988). This literature provides a theoretical basis that a negative wealth effect arises from share repurchases in an efficient market where investors rationally anticipate predatory trading behavior by well-informed management. While theoretically plausible, the material impact of these issues is not clear. Moreover, it is difficult to reconcile the clearly negative value implications from this theory with the positive, initial market reaction generally observed. Another example can be found in a more recent paper by Massa, Rehman and Vermaelen (2005). They propose that firms in concentrated industries may choose to announce buybacks following the buyback announcements of competitors as part of a strategic reaction.

${ }^{4}$ Early examples include Vermaelen (1981) and Comment and Jarrell (1991). More recent examples include Bhattacharya and Dittmar (2004), Oded (2005) and Peyer and Vermaelen (2005).
} 
category received a response by at least some managers lends some credence to the notion that managers may be using repurchases in a way that deviates from conventional economic stories that are related to enhancing shareholder wealth.

Further, suspicions have been raised as to the signaling content of open-market buybacks given the structural flexibility managers have to forego purchasing any shares, thus opening them for abuse as a form of "cheap-talk." In contrast to fixed-price and Dutch-auction tender offers, open market buybacks (by far, the most prevalent repurchase mechanism) are not firm commitments. Several studies find that many programs go unfulfilled (Stephens and Weisbach (1998) consider U.S. cases while Ikenberry, Lakonishok and Vermaelen (2000) report evidence for Canada). This inherent flexibility affords managers the chance to initiate programs, even if their intention to acquire stock is not based on a perception of misvaluation or some other value-enhancing motive. Not surprisingly, early work in the signaling literature by Comment and Jarrell (1991) finds open-market programs to be the least informative signaling mechanism available for reacquiring stock. ${ }^{5}$

Direct measures of managerial intent regarding any transaction, of course, are unobservable. Here, we consider earnings quality as a proxy for the propensity of managers to falsely signal or otherwise potentially mislead investors through a buyback program announcement. This flows as an extension of an emerging literature regarding earnings management. For example, Chan, Chan, Jegadeesh and Lakonishok (2004) argue that a relation may exist between earnings quality and managerial intent. Specifically, they reexamine the relation between earnings quality and future stock performance and assert that earnings management may reflect an intention by managers to manipulate investors. This pressure to affect market prices may come from a variety of sources (not the least of which may in part be due to the structure of managerial compensation). To the extent investors have a myopic view of earnings (for example, Hand (1990)) and fixate on reported earnings, thus overlooking the fundamental assumptions needed to justify those earnings, these strategies may have some efficacy. Sloan (1996) points out that while management may make discretionary accounting decisions to inflate current earnings, the accruals used to accomplish this are not sustainable in the long-run. Nevertheless, when organic earnings growth is not in line with the market's expectation, managers may indeed be tempted to use accruals to inflate earnings and thus mislead investors (at least in the short-term).

This behavior to affect market perception may arguably carry over into using open market buyback programs in a similar fashion to mislead investors, especially if prior attempts at rallying market support through inflated accruals have not boosted stock prices. If the cost (direct and/or indirect to either

\footnotetext{
${ }^{5}$ In fact, Ikenberry and Vermaelen (1996) provide a theoretical framework which suggests nearly all firms should be expected to adopt low-cost, flexible buyback programs. In such a world, one would expect these announcements to lose signaling power.
} 
management or to the firm) of announcing an open market program is low and investors are not able to discern the intention of company executives at the announcement, it may be the case that managers, aware of their otherwise positive signaling effects, will consider share repurchases as another mechanism with which to mislead investors and boost stock prices. ${ }^{6}$

We investigate this alternative view of buybacks by considering the quality of a firm's reported earnings around the time of a buyback announcement. Some key questions of interest are: 1) given that we cannot directly verify managerial intent, is there any evidence which suggests that the managers of buyback firms with low earnings quality are under pressure to boost stock prices?, 2) do we find any evidence that investors recognize this pressure and react accordingly?, and 3) is the operating and long-run stock return performance of suspect buyback firms worse compared to the generally favorable case?

We examine a sample of 7,725 open market repurchases announced in the U.S. between 1980 and 2000. Generally speaking, managers who use aggressive accounting techniques do indeed appear to be under pressure to take action to reverse what is otherwise a negative information environment; immediately prior to the announcement of a repurchase, these firms are experiencing problems including a relatively sharp decline in abnormal stock returns. Sales are dropping, realized earnings announcement returns are significantly negative and financial analysts on average are making negative forecast revisions with respect to future earnings. Looking at the managers themselves in these low earnings quality firms, they tend to exercise executive stock options at higher rates and also tend to own more vested, exercisable options than managers of other buyback firms.

These results paint a picture which suggests that managers could be prone to use an open market repurchase program in a manner that might mislead investors. In the short-run, we find that, consistent with the evidence regarding earnings myopia, the market does not sort out differences in earnings quality across buyback programs as they are announced. In both high and low earnings quality firms, the initial market reaction is about the same, slightly higher than $2 \%$.

In the long run, the results are generally consistent with the notion that managers may have been using buybacks as a means of generating market support. The operating performance of low earnings quality firms significantly deteriorates after a buyback announcement. For stock returns, in contrast to what we see more generally in stock buybacks, the long-horizon return performance of poor earnings quality firms is not significantly different from zero. When we focus more narrowly on more suspicious cases where one might expect managers to be more desperate, our findings generally strengthen.

\footnotetext{
${ }^{6}$ In a recent talk, Jensen (2005) strongly argues that earnings management is unethical and akin to "lying." While this may perhaps be an extreme view, his argument lends support to the notion that managers who adopt aggressive accounting practices may be doing so in an attempt to mislead investors.
} 
This conclusion runs counter to a well-established literature which commonly portrays repurchases in a generally beneficial light. In at least a portion of buyback cases (and in a manner consistent with what some of the literature has suggested with respect to these weak signals), managers appear intent on taking advantage of positive signaling effects from buyback programs which investors are not able to discern in the short-run. Just as managers in the short-run are able to manipulate earnings to their advantage, it also appears that some companies may be using share buyback announcements as low-cost signals with which to mislead investors.

Of course given that we do not have true insight into managerial intent, it is possible that some alternative explanation might be able to explain the results we find for poor earnings quality firms. For example, managerial hubris is one such possibility; managers in these poorly performing firms may in fact have misguided or over-inflated views as to the value of the firm and thus may be prone to announce a share buyback which they truly consider a value-enhancing decision. Yet, the result that poor earnings quality firms actually buy back less than other buyback firms and that executives in poor earnings quality firms exercise more stock options than others before the buyback announcement are inconsistent with managerial hubris being a dominant factor. As a final check, we consider whether other explanations might account for our findings. The results support the conclusion that in at least some cases, managers may be misleading the market. While there is no impact in the long-run as one would expect, these misleading signals appear to have some efficacy in the short-term.

The next section describes the data and methodologies. Section 3 presents summary statistics including announcement returns and firm characteristics. Section 4 reports long-run stock return and operating performance. In Section 5, we consider alternative return estimation models and also investigate alternative explanations such as undervaluation, distributing free cash flow, increasing leverage, and reversing dilution from employee stock options. We summarize the paper in Section 6.

\section{Data and methods}

\subsection{Sample formation}

We form a sample of open-market repurchase announcements from two sources. The first is from the Wall Street Journal Index for the period 1980-1990; the second is from Securities Data Corporation (SDC) which begins comprehensive coverage in 1985. We evaluate return and operating performance four years subsequent to the buyback announcement and thus terminate our sample at the end of 2000. We eliminate firms whose return information is not present on CRSP or whose accounting information is not available on annual Compustat. To reduce time clustering, we eliminate announcements that occurred in the fourth quarter of 1987. To avoid the impact of skewness in our long-run return estimates, we exclude firms whose share price at the time of repurchase announcement is below \$3 (Loughran and 
Ritter (1996)). The final sample includes 7,725 separate cases.

\subsection{Measuring earnings quality}

Accounting accruals are a common measure of earnings quality (Beneish and Vargus (2002), Chan, Chan, Jegadeesh and Lakonishok (2004)). Accruals are derived from an accounting identity which links earnings and cash flows. Specifically, earnings are equal to cash flows plus accruals. The intent of accruals is to allow those preparing accounting statements to make adjustments that deviate from cash flows; deviations which, in their opinion, better reflect the firm's fundamental operations. While standards are in place governing how these accruals are determined, a substantial degree of subjectivity exists. This flexibility provides an opportunity for executives to potentially distort reported earnings.

In a purely efficient market, these maneuvers are argued to be ineffectual. Yet, a rich literature including Hand (1990) and Sloan (1996) argues that investors appear to "fixate" on reported earnings and either ignore or are unaware of the accruals affecting these earnings which may be less likely to recur in the future. A recent paper by Dechow and Ge (2005) lends credence to the idea that investors may misunderstand the transitory impact of special accounting adjustments on earnings. To the extent that firms rely more heavily on this source of earnings, managers may be able to guide or shape investor behavior. Eventually though, if a firm is reporting high earnings due to high discretionary accruals, a large portion of this result may not be sustainable.

To gauge earnings quality, we follow Sloan (1996) and Chan, Chan, Jegadeesh and Lakonishok (2004) to define accruals in equation (1), with Compustat annual item numbers in parentheses.

$$
\text { Accruals }=(\Delta \mathrm{CA}-\Delta \mathrm{Cash})-(\Delta \mathrm{CL}-\Delta \mathrm{STD}-\Delta \mathrm{TP})-\mathrm{DEP}
$$

where

$$
\begin{aligned}
\Delta \mathrm{CA} & =\text { change in current assets (4) } \\
\Delta \mathrm{Cash} & =\text { change in cash (1) } \\
\Delta \mathrm{CL} & =\text { change in current liabilities (5) } \\
\Delta \mathrm{STD} & =\text { change in debt included in current liabilities (34) } \\
\Delta \mathrm{TP} & =\text { change in taxes payable (71) } \\
\mathrm{DEP} & =\text { depreciation and amortization expense (14) }
\end{aligned}
$$

Accruals are measured at the fiscal year-end prior to the repurchase announcements. We assume a four-month reporting lag to avoid look-ahead biases and scale all accruals by average total assets (TA).

One shortcoming of this approach is that some portion of total accruals is not discretionary, but rather is tied directly to firm growth. For instance, as high growth firms increase in scale, one expects to observe increases in accounts receivable and inventories. To the extent that there are not off-setting changes in current liabilities, these findings may lead to high accruals. To control for this, we follow 
convention in the earnings management literature and decompose accruals using the Jones (1991) model

$$
\frac{\text { Accruals }_{i}}{T A_{i}}=a_{0} \frac{1}{T A_{i}}+a_{1} \frac{\Delta \text { Sales }_{i}}{T A_{i}}+a_{2} \frac{P P E_{i}}{T A_{i}}+\varepsilon_{i},
$$

where $\Delta$ Sales is the change in sales (Compustat annual item number of 12) and PPE is property, plant and equipment (Compustat annual item number of 7). Consistent with prior work, we define non-discretionary accruals (NDA) as the fitted values from this model for a given firm. Discretionary accruals (DA) are thus defined as the residual for this case away from its expected value. We follow Teoh, Welch and Wong (1998) and estimate model (2) each year for each of the 48 Fama-French (1997) industries using all NYSE/AMEX/NASDAQ stocks. ${ }^{7}$ We then compute NDA and DA for each repurchase firm as:

$$
N D A_{i}=\left(\hat{\alpha}_{0}+\hat{\alpha}_{1} \Delta \text { Sales }_{i}+\hat{\alpha}_{2} P P E_{i}\right) / T A_{i} \quad D A_{i}=\text { Accruals }_{i} / T A_{i}-N D A_{i}
$$

We create relative measures of earnings quality by calculating DA values for each firm with available data on Compustat. Quintile cutoff points are then defined across this universe each year, thus allowing us to identify DA quintile ranks for each sample firm.

\subsection{Measuring abnormal long-run stock returns}

We estimate abnormal stock performance both prior to and subsequent to a buyback announcement using a variety of techniques. Because of its ability to provide a more meaningful interpretation, much of our analysis relies on an annual buy-and-hold returns approach (BHRs). Barber and Lyon (1997) point out that the implied investment strategy from this procedure is both feasible and replicable, and seemingly indicative of what a long-horizon investor might earn. For each sample firm, a benchmark is formed using five firms with comparable market-cap and book-to-market ratio. Statistical inferencing is accomplished via a bootstrap method as advocated by Lyon, Barber and Tsai (1999). The details of this rather standard method are described more fully in the Appendix.

\subsection{Measuring abnormal operating performance}

We evaluate operating performance using a variety of metrics including earnings, accruals, cash flows and sales. We also consider performance using Return on Assets (or ROA) and use this measure to identify a matching control-firm from which to estimate abnormal operating performance. Here, ROA is defined as EBITDA (operating income before depreciation, Compustat item 13) scaled by average total assets. The choice of EBITDA is recommended by Barber and Lyon (1996) and is commonly adopted in many papers which evaluate operating performance (for example, Jain and Kini (1994) for IPOs,

\footnotetext{
${ }^{7}$ For two-digit industries with less than 10 firms in a given year, we parameterize the model using coefficients estimated from all available firms at that time.
} 
Loughran and Ritter (1997) for SEOs, Grullon and Michaely (2004) for repurchases).

We define abnormal operating performance by taking the ROA of each buyback firm and subtracting the concurrent ROA of a matching firm based on industry and pre-event performance. More specifically, we identify matching firms for a given target by locating all firms with the same two-digit SIC code and then choosing the company with the closest pre-event ROA as that of the sample firm. We require that the matching firm's pre-event ROA is within the range of $(80 \%, 120 \%)$ of the sample firm's pre-event ROA. Since the ROA for some sample firms is close to zero, this approach may be overly restrictive. In these cases, we check for pre-event ROA to be within \pm 0.01 of that of the target firm. If no match is identified at this point, we relax the industry requirement to the 1-digit SIC industry and repeat the above steps. If this fails, we remove the industry requirement, search across all firms, and identify the firm with the closest match, thus minimizing the following condition ${ }^{8}$ :

$$
\min \left|\mathrm{ROA}_{\mathrm{t}-1, \text { sample firm }}-\mathrm{ROA}_{\mathrm{t}-1, \text { matching firm }}\right|
$$

\section{Firm characteristics around share repurchase announcements}

\subsection{Summary statistics}

Table 1 reports summary information for firms in our sample. Panel A reports summary information for the overall sample period as well as two sub-periods. The average five-day announcement-period abnormal return is $1.79 \%$ and significantly positive, although the mean return is lower in the more recent sub-period.

Consistent with earlier studies, firms announcing buyback programs are generally poor performers prior to the announcement, a result that is in sharp contrast to firms choosing to issue stock. The mean raw return for sample firms in the year prior to the announcement is $1.80 \%$; adjusted for size and book-to-market effects, the abnormal return is $-12.58 \%$. The mean intended buyback amount is about 7.5\% of the share base. Panel A also reports mean rank characteristics for size, $\mathrm{B} / \mathrm{M}$ and discretionary accruals. Generally speaking, the typical buyback firm in our sample is similar to the underlying universe with respect to market-cap, $\mathrm{B} / \mathrm{M}$, and their use of accruals.

Panel B reports evidence similar to Panel A, but conditioned on discretionary accruals (DA) quintiles. For firms ranked in the highest or most aggressive DA quintile, the unexpected accrual is $+13.7 \%$ of their total assets. Interestingly, the average year -1 raw return for these firms is quite low, $-11.5 \%$. On an

\footnotetext{
${ }^{8}$ Among repurchase firms with valid ROAs, 73.3\% find a match using a 2-digit SIC-code industry and ROA filter, 9.8\% find a ROA filter-matched firm within the 1-digit SIC-code industry level. Further, 4\% meet the ROA filter restriction but not industry requirement. The remaining $12.8 \%$ of repurchase firms are matched without an industry filter according to equation (6).
} 
adjusted basis, these firms show dramatically poor abnormal performance relative to the other firms in the year prior to the announcement. This result is consistent with the notion that compared to the general case, managers in high DA firms may have been under greater pressure to reverse a sagging share price.

Turning to the immediate market reaction to the buyback announcement, there is no clear pattern in announcement returns between high and low DA groups; the stock market does not seem to pay attention to the earnings quality of firms when they announce a share repurchase. Here, for both high and low DA groups, the announcement-period abnormal return is about the same (slightly over 2\%) with no significant difference between the groups. Although not reported here, we examine this conclusion more carefully using multivariate regression analysis to control for various factors including, for example, market-cap effects and the overall size of the buyback program. We find no evidence that the market distinguishes among programs of varying earnings quality.

As a further examination as to whether we might better identify firms under pressure to announce a buyback program, we subdivide High DA firms into two groups on the basis of their abnormal stock performance in the quarter preceding the buyback announcement. Here, we see that High DA firms with relatively poor prior abnormal performance (High-L) lost more than $20 \%$ of their market-cap in the preceding year; on a relative basis, these firms underperformed by $-40 \%$. Among these more extreme cases, the mean 5-day abnormal market response was 2.3\%. This point estimate is not lower, but rather slightly higher compared to the High-H subset; the difference in market reaction between the two sub-groups is not significant at conventional confidence levels.

\subsection{Operating performance, earnings announcement effects and earnings forecast revisions}

To better understand the overall performance of repurchasing firms with low earnings quality, we turn our attention to operating performance prior to the buyback announcement. In Figure 1, we plot the time-series pattern of four operating performance measures: earnings (operating income after depreciation), accruals, cash flows (earnings minus accruals), and sales for five fiscal years prior to the announcement. $^{9} \quad$ In Panel A of Figure 1, we focus on the two extreme DA quintiles.

For the highest DA quintile firms, earnings significantly increase before the announcement of a share repurchase even though sales are actually decreasing during the pre-announcement period. Further, while earnings are increasing, cash flows are dropping in years -2 and -1 . By definition, it is the high accruals that these firms are employing that allow them to maintain comparatively high earnings even in the presence of declining sales and cash flows. While it is difficult to appreciate all the reasons why managers in high DA were adopting aggressive accounting conventions, the evidence is consistent with the general story that they were under pressure to manage earnings in the face of what was otherwise declining operating performance.

${ }^{9}$ Each of these measures is scaled by average Total Assets over the year. 
Conversely, for firms ranked in the lowest DA quintile, we see a mild decrease in reported earnings over this same period of time. Sales, however, are rather flat and cash flows are actually rising quite rapidly. The mild decrease in earnings in a rising cash flow environment is explained by high negative accruals. These are firms with comparatively conservative accounting practices.

In Panel B, we plot operating results for the highest DA quintile conditioned into two sub-groups on the basis of the abnormal return in the quarter prior to the announcement. For High DA firms with low prior abnormal returns (High-L), cash flows fall more than otherwise. Moreover, their accruals and reported earnings show more dramatic growth compared to the High-H sub-group. This is consistent with the idea that among all High DA firms, managers with poor return performance prior to the buyback announcement may have been under even greater pressure compared to High DA firms in general.

In Table 2, we turn attention to the market reaction to quarterly earnings announcements preceding the buyback to gauge how the market is reacting to the release of operating performance. To the extent that these news releases are not anticipated, we gain some sense of market surprise. Panel A reports earnings announcement returns for each of the four quarters prior to buyback announcement for the lowest and highest DA quintiles. We see some evidence that the average earnings announcement return is less favorable for the highest DA quintile firms in the year prior to the buyback announcement. This is particularly true in the quarter immediately prior to the buyback announcement. Here, the average abnormal market return for the lowest DA quintile is $-0.11 \%$ and not significantly different from zero. On the other hand, the average abnormal return of the highest DA quintile is $-0.99 \%$ ( $t$-statistic $=-4.35$ ). On average, the market is receiving a negative information shock for High DA firms just prior to the buyback announcement. Not surprisingly, if we focus more narrowly on the High-L sub-group, the disappointment in the earnings release just prior to the buyback announcement is worse.

In Panel B of Table 2, we investigate how equity analysts are revising their forecasts. Here, we report the proportion of negative abnormal quarterly earnings forecast revisions for the lowest and highest DA quintile firms in the year preceding the buyback announcement. We examine revisions based on both the average and the median earnings per share (EPS) estimate. ${ }^{10}$ The results show that analyst opinion is running pessimistic in High DA firms; a result consistent with the return evidence reported earlier. This trend in High DA firms accelerates in the two quarters preceding the buyback announcement.

Consistent with the poor earnings announcement return in the quarter prior to buyback initiations, these results suggest that both investors and financial analysts are disappointed in the months preceding a

\footnotetext{
${ }^{10}$ Abnormal forecasts revisions are calculated by subtracting the average change in analysts' average (median) EPS forecasts during all months available at the IBES data (excluding months -6 to 6 around the month end of the calculation), from the average (median) forecast revision.
} 
buyback announced by firms using aggressive accounting policies. Even though these firms are generating comparatively high reported earnings, these earnings are driven to a large degree by managerial discretion. Between High-L and High- $\mathrm{H}$, we do not find any significant difference in negative abnormal earnings forecast revisions during the quarter before the announcement - both groups show a rather large increase in negative forecast revisions.

Overall, the evidence here is consistent with the idea that managers in high DA firms in our sample may have been under pressure to reverse an otherwise negative trend in market events.

\subsection{Executive stock options}

As a final consideration as to whether managers in low earnings quality firms might also be feeling pressure at a more personal level, we evaluate both option exercise activity as well as unexercised option ownership positions during the two fiscal years around the buyback. S\&P's ExecuComp provides compensation information for the top 5 executives of the firms in S\&P 500, S\&P MidCap 400 and S\&P SmallCap 600 indices. While this covers only a portion of our sample, we consider those firms which are followed in this database and report the results in Table 3.

Both the chief executive officer alone and the top five executives together of the highest DA quintile firms (especially those in High-L sub-group) exercise a significantly greater amount of stock options during the fiscal year before the announcement compared to those of the lowest DA quintile firms $(0.17 \%$ vs. $0.09 \%$ for CEOs and $0.37 \%$ vs. $0.26 \%$ for top five executives). Considering that the vast majority of shares acquired through executive option exercises are sold almost immediately (Ofek and Yermack (2000)), this would seem to indicate that top managers of the highest DA quintile firms are largely reducing their equity exposure prior to a buyback announcement. During the year of buyback program, this selling pressure is not quite so evident. These results suggest that in the year prior to the announcement of the buyback program, managers of low earnings quality firms seemingly did not behave in a manner consistent with the undervaluation hypothesis. They are exercising options at a comparatively higher rate despite the fact that these contracts are becoming less in-the-money due to poor stock returns prior to buyback announcements.

Turning to overall unexercised, vested option holdings (which would include both in-the-money and out-of-the-money options), we see that ownership is comparatively greater in High DA firms in both the year preceding and the year of a buyback announcement. This is again consistent with the idea that managers of low earnings quality were indeed incentivized to pay attention to stock prices; their decision to be aggressive in reporting earnings may have been in response to a general sense of pressure or need to support their share price. 


\section{Long-run Performance and Actual Buyback Activity}

The evidence to this point suggests that managers in buyback firms with low earnings quality may very well be under pressure to take some action or set of actions to stop negative sentiment in the market. Very poor stock returns, deteriorating operating performance, negative earnings announcement effects, negative revisions of financial analysts' earnings forecasts, and more option exercises and holdings by managers prior to buyback announcements are consistent with this view. In the short-run, we see no evidence that the market reaction is any different between high and low DA firms. While it is possible that our use of discretionary accruals as a proxy for manager intent may be quite noisy, the results suggest that in the short-run, the market is not recognizing and responding differently to these potentially manipulative behaviors by management.

In this section, we consider long-run return and operating performance evidence. A rich literature reports evidence of improved performance subsequent to a buyback announcement, particularly with respect to abnormal stock performance. This result is consistent with the idea that, generally speaking, buyback programs are beneficial to shareholders and motivated by some meaningful economic benefit. On the other hand, to the extent that a sub-set of buybacks is manipulative in intent, we do not expect to find this same general evidence. Absent some fundamental economic benefit, we do not expect to observe any material long-term abnormal performance for High DA firms, either operationally or measured by stock performance.

\subsection{Long-term stock performance}

Table 4 shows the long-term buy-and-hold returns (BHRs) of sample firms. Consistent with prior studies (e.g., Ikenberry, Lakonishok and Vermaelen (1995)), we see a turn-around in abnormal returns surrounding a buyback announcement for the overall sample. While the average prior one-year abnormal return is $-12.6 \%$, the average compounded four-year post-announcement abnormal return is 15.6\%. When long-term performance is conditioned by DA quintile, we find strikingly different results. For Low DA firms which are considered to have high earnings quality, the four-year post abnormal return is $36.9 \%$, with the $p$-value of 0.000 . Conversely, for the highest DA quintile, the long-term abnormal return is $7.8 \%$. This amount is much lower and not significantly different from zero at conventional confidence levels. Moreover, we also observe a monotonically negative relationship between the DA quintile rank and long-term abnormal performance. These results suggest that earnings quality is an important factor associated with long-run return performance. In fact, the highest DA quintile is the only group reported here which does not show a statistically significant long horizon drift. When the highest DA quintile is further divided into two groups based on the stock performance in the quarter prior to buyback announcement, we find more striking differences. For High-L firms where management may have been under greater pressure, the average abnormal return four years after the announcement is 
negative, $-5.8 \%$. Yet for High-H firms, the four-year post-announcement drift is positive and significant, $21.6 \%(p-$ value $=.044)$.

This result is consistent with the idea that the motivation for announcing a buyback in these low earnings quality firms, especially those with poor stock performance, may differ from the more general case with better earnings quality. In Panels B and C, this conditional evidence is reported separately for two sub-periods, 1980-1990 and 1991-2000. The evidence, generally speaking, is stable between the two sub-periods. ${ }^{11}$

\subsection{Operating performance}

Table 5 reports the operating performance for the lowest and highest DA quintile firms. Panel A reports median unadjusted ROAs while Panel B reports industry adjusted performance. Panel C cumulates this abnormal performance in the post-announcement period. Taken together, there are noticeable differences in operating performance between the two extreme DA groups. Low DA firms show a dramatic increase in relative operating performance after the buyback announcement. For example, while abnormal ROA in year -1 is zero (by definition), it jumps to $+1.71 \%$ in year 1 and further to $+3.06 \%$ in year 2 . Conversely, we do not see such a rebound in High DA firms. Instead, relative operating performance for firms using aggressive accounting practices at the time of buyback announcement decreases from zero to $-.86 \%$ in year 1 ( $\mathrm{p}$-value $=.006$ ). In year 2 , the point estimate increases slightly although the result is not statistically significant.

When we focus more narrowly on High-L firms where suspicion about managerial motives is greater, poor performance is indeed quite noticeable in years +1 and +2 . Here, the abnormal ROA in these two years is $-1.62 \%(p$-value $=.002)$ and $-2.30 \%(p$-value $=.007)$, respectively. For this group, the point estimates continue to remain disappointing in years +3 and +4 .

Panel C suggests that when measured cumulatively, we see meaningful differences, both statistically as well as economically, in operating performance between Low and High DA firms.

\subsection{Actual buyback activity}

We have been using earnings quality as a proxy to measure the potential of managers to manipulate or mislead investors. To the extent that there is less of an economic reason supporting these cases (and that monitoring actual buyback activity is difficult for investors to accomplish), our hypothesis suggests that low earnings quality firms should repurchase fewer shares than other firms. This would be particularly so if the share repurchase was narrowly intended to be a false signal to the market.

\footnotetext{
11 Although not reported here because of space constraints, we also estimated return evidence for the High-L sub-group in these two sub-periods. Consistent with the manipulation story, we find no evidence of the more generally positive return drift for this group; the mean abnormal return drift is marginally negative. As a check to verify that these findings are not driven by extreme cases, we also estimated this analysis winsorizing the top and bottom $1 \%$ of the sample. The results are similar to those reported in Table 4.
} 
To investigate this, we evaluate actual buyback activity for sample firms during the year following the program announcement. Here, we estimate the actual buyback amount from the funds used to redeem stock on Compustat after adjusting for concurrent changes in preferred stock, (the same method described in Stephens and Weisbach (1998) and Dittmar (2000)). Although Stephens and Weisbach (1998) show that this method is biased upward, they argue it is the preferred approach for deciphering actual repurchase activity. ${ }^{12}$

Due to data limitations with this variable in Compustat, our sample is reduced to 6,365 observations. Panel A of Table 6 reports actual buyback dollar volume divided by average market-cap during the first year after the repurchase announcement, the intended number of shares announced in the program relative to total number of shares outstanding, and the ratio of the actual buyback amount to the intended amount. $^{13}$ The results show that, generally speaking, firms on average purchase between $58 \%$ and $60 \%$ of their intended buyback amount during the first year of the program. For High DA firms though, the results are more modest. Here, the first-year completion rate is roughly 54\%. The difference in completion rates between the highest and lowest quintile groups is significantly different from zero. While the point estimate for intended program size is slightly higher for High DA firms, the lower completion rate appears to be affected by significantly lower actual buyback activity. As before, we also report separate results for the two sub-groups within the High DA quintile. Consistent with the notion that managers under a higher degree of pressure may choose to provide a false signal, completion rates in High-L firms are below that of High-H firms.

Stephens and Weisbach (1998) document that firm characteristics, such as prior returns and cash flows, may affect the amount of stock firms choose to repurchase. To check whether this might be affecting our findings, we perform Tobit regressions of actual buyback amount ${ }^{14}$, the results of which are reported in Panel B of Table 6. Consistent with the more general economic motives one might expect such as a desire by management to respond to mis-pricing and/or adjust leverage, the regressions show that firms with large repurchase programs and high book-to-market ratios tend to buy back more stock in the first year of the program. Consistent with Stephens and Weisbach (1998), cash is also an important factor. Yet after controlling for these economic factors, High DA firms still tend to buy back less stock than one would otherwise expect. Even when we assume some degree of foresight by adding into the regression the future four-year abnormal return (a variable with strong power), the negative relationship between DA and buyback activity does not change.

\footnotetext{
12 Further, Stephens and Weisbach (1998) also find that a substantial portion of buyback activity occurs in the first year of the buyback program.

13 As in Stephens and Weisbach (1998), we truncate extreme values of the actual to intended buyback ratio to between zero and 100 percent for a given firm. This truncation motivates our use of Tobit rather than OLS regression analysis in Table 6.

${ }^{14}$ Tobit regressions using the actual to intended ratio produce qualitatively similar results.
} 
Clearly, we find evidence that High DA firms do repurchase shares, a result which suggests that management in this subset was not completely intent on misleading investors by conveying false signals. On the other hand, our metric of managerial intent is noisy and a variety of factors may be working in these cases. Taken collectively, the evidence would seem to indicate that some other factor aside from distributing free cash flow, responding to mispricing or altering capital structure is motivating buybacks in cases where managers are using aggressive accounting practices. The results in Table 6 suggest that managers in firms with low earnings quality appear to be behaving in a manner consistent with the manipulation story.

\section{Alternative explanations for the performance of low earnings quality firms}

In general, firms announcing a stock buyback show deteriorating operating and stock market performance prior to the announcement. The evidence in Section 3 indicates that the decline is more profound in firms which employ aggressive accounting practices. While it is indeed the case that reported, bottom-line earnings (comparatively) are not suffering due to the use of aggressive accruals, both unadjusted as well as normalized pre-announcement stock returns are noticeably worse for these special cases. General operating performance is falling and both investors and analysts appear to be revising their expectations downward. These results are consistent with the notion that this sub-set of managers who made discretionary decisions to report poor quality earnings were under greater pressure to boost stock prices prior to their buyback announcement.

While the evidence to this point is seemingly consistent with the manipulation story, it is plausible that alternative explanations might be at work. For example, given that managerial intent is unobservable, one cannot casually rule out undervaluation as a driving motive. Poor pre-announcement performance has been argued in other papers as direct support of the mispricing hypothesis, one of the more popular contentions for why managers buy back stock. In addition, skeptics often raise concern that long-term stock performance is subject to "bad model problems" as pointed out by Fama (1998). On a related point, discretionary accruals more generally have been argued as an underlying factor priced in the cross-section.

In this section, we explore some robustness issues relating to the manipulation story. We begin with a robustness check of the return evidence to address the bad model problem. Next, we dig deeper into considering whether conventional theories such as free cash flow, mis-pricing or altering capital structure can explain the evidence we are seeing for poor earnings quality firms.

\subsubsection{Bad model problems}

A potential problem with the BHAR approach is that the empirical bootstrap used to evaluate 
statistical significance may suffer from cross-sectional correlations in the residual returns, a point argued by Fama (1998), Mitchell and Stafford (2000), and Brav (2000). The concern is that long holding periods, by design, lead to overlapping time periods in the observations and may lead to cross-sectional correlation in the abnormal returns if the underlying return model is mis-specified. While this is fundamentally a problem of not understanding the true return generating function, the concern that significance may be overstated is a valid point given our four-year holding periods and the thousands of cases we consider.

While our concern is primarily a lack of significance in a portion of our sample, we nevertheless accommodate this by reporting return evidence using a calendar-time approach. The Appendix provides a more careful description of the Carhart (1997) four-factor model. Here, hundreds of return observations at a single point in time are boiled down to a single observation. Briefly, this approach not only provides a different method for estimating abnormal return performance with perhaps more appealing significance properties, but also allows us to easily control for other first-order effects such as momentum as well as the size and book-to-market effects we controlled for earlier. ${ }^{15}$ Perhaps more importantly, recent papers in the accounting and finance literatures have identified discretionary accruals as a priced factor in the cross-section (Xie (2001) and Chan, Chan, Jegadeesh and Lakonishok (2004)). To exclude the possibility that the comparatively low post-announcement return performance of poor earnings quality buyback firms is simply the manifestation of a more general effect, we amend the Carhart model and add discretionary accruals as an additional factor. ${ }^{16}$

Table 7 reports the results for calendar-time portfolios formed assuming both equal- and logvalue-weighted methods. Point estimates for the intercepts are positive for each DA quintile 1 to 4 under both investment strategies and the intercepts are significant at conventional levels. For High DA firms in quintile 5 , the intercepts are not significant as the point estimates are close to zero $(0.07 \%$ and $0.10 \%$ respectively for the equal- and the log-value-weighted approaches). We also report evidence for a self-financing, arbitrage portfolio labeled in the row "Low - High.” This portfolio assumes long positions in the lowest DA quintile and short positions in the highest DA quintile. The intercepts are significant at conventional levels and indicate that returns in the highest DA quintile are indeed comparatively low.

As before, we consider the manipulation story more carefully by subdividing the poor earnings quality quintile by the abnormal return in the quarter preceding the buyback announcement. Given this return-based sorting method, the momentum control provided through the calendar-time approach has

\footnotetext{
${ }^{15}$ Numerous studies adopt this approach. Two recent examples include Clarke, Dunbar and Kahle (2004) and Eberhart, Maxwell and Siddique (2004).

16 Although not reported here, we also applied the simple Carhart model without controlling for discretionary accrual effects. The findings are similar to those reported in Table 7.
} 
some appeal. Yet consistent with the findings to this point, we do not find evidence of a positive drift in firms where managers conceivably were under greater pressure to buy back stock. Firms classified as High-H have positive and significant intercepts, while those ranked as High-L do not.

The results suggest that the documented long-term return evidence is not likely to be primarily the consequence of a bad model problem. Firms with aggressive reporting practices do not show the same long-horizon abnormal performance more generally observed in buyback companies. This result holds even when we control for the findings that firms with high discretionary accruals generally report lower long-run returns in the cross-section. ${ }^{17}$

\subsection{Undervaluation, free cash flow, leverage and dilution from employee stock options}

Next, we consider whether these results somehow reconcile with other commonly mentioned reasons for why firms buy back stock. Chan, Ikenberry and Lee (2004) recently show that among several plausible motivations for share repurchases, undervaluation appears to be a primary one. Clearly, the comparatively lower post-announcement return and operating performance for firms in the highest DA quintile is not consistent with the undervaluation hypothesis. Moreover, given that prices are falling prior to the buyback announcement in the High DA cases, if executives were convinced their shares were undervalued, one might expect a decrease in the rate of executive option exercise activity. Evidence in Table 3 suggests just the opposite; High DA firms demonstrate high option exercise activity.

Yet corporate finance theory also suggests that firms may use buybacks to disgorge cash and reduce free cash flow or to adjust capital structure. We investigate this in Table 8 by reporting industry-median-adjusted abnormal cash relative to total assets and leverage ratio for each discretionary accrual group. When considering the first hypothesis, obtaining a careful handle on "slack" resources in a given firm is not straightforward. Rather than use a flow measure of free cash flow that might be subject to measurement problems driven by the choice of accrual level, we use a stock measure defined as cash plus short-term investments (Compustat item 1) over total assets. This same measure was recently used by Grullon and Michaely (2004) to examine the free cash flow hypothesis. ${ }^{18}$ We apply an

\footnotetext{
${ }^{17}$ In unreported work, we also consider a variety of other robustness checks. To further address the overlapping nature of our data, we considered evidence which excludes follow-up buyback announcements within the four-year horizon we apply in Table 7. Here, the sample is roughly cut in half. Both the BHAR and the five-factor model results are qualitatively similar to those reported in Tables 4 and 7 . We also investigated whether our findings were sensitive to our estimate of discretionary accruals. We follow the same method of Kothari, Leone, and Wasley (2005). They design a performance-matched discretionary accrual measure by subtracting a matching firm's DA from that of a given sample firm where the matching firm is selected to have a similar return on assets (ROA) and is from the same industry. Here as well, the long-run stock evidence is generally similar to what we report here.

${ }^{18}$ For example, Lehn and Poulsen (1989) use a flow measure defined as EBITDA - income tax + changes in deferred tax - interest expenses - dividends for preferred stocks - dividends for common stocks. The downside to such an approach is that this particular measure is directly affected by accruals. Given our context, this measure, by definition, is not an appealing way to examine the free cash flow hypothesis. Nevertheless, as a robustness check, we did use this flow-based measure; qualitatively, the results do not change.
} 
industry-median adjustment by subtracting the median level of cash plus short-term investments over total assets of each firm's respective industry.

We see in Table 8 that before the buyback announcement, abnormal cash for each DA quintile is significantly above that of their industry peers, a result consistent with conventional economic theory. This is particularly true for firms in the lowest DA group where cash is highest, $9.05 \%$ of total assets above the industry norm. Even for firms in the highest DA group, cash is $3.37 \%$ of total assets above the industry norm albeit it is significantly less than that of low DA firms.

Nevertheless, given what are still significantly positive levels of cash balances in High DA firms, it may be the case that managers in these high accrual firms may have been motivated to announce a buyback in order to reduce these excess cash balances. Yet, when we focus on the change in this measure from the year before to the year after the announcement, we reject this hypothesis. While we generally see significant decreases in cash for most DA quintiles, the change in the point estimate for High DA firms is close to zero and the result is not significant. The fact that cash balances did not decline much is also consistent with the reduced level of actual buyback activity documented in Table 6 for High DA firms. ${ }^{19}$

A second primary reason firms repurchase stock is to alter capital structure by increasing leverage. In a similar fashion, we report industry-adjusted leverage ratios defined as the ratio of total debt (total current liabilities plus total long-term debt, Compustat item 5 plus item 9) to total assets. Here, we also find evidence consistent with economic theory for most DA quintiles. Industry-adjusted leverage ratios are in general less than the industry norm except for Low DA firms. Even for High DA firms, leverage ratios are significantly below their industry medians. This is consistent with the possibility that managers in High DA firms might be considering altering capital structure through a buyback. However, when we focus on changes in leverage ratios between year -1 and year 1 , we do not find any significant increase in leverage for High DA firms.

It has been argued (particularly in the popular press) that stock repurchases are affected by compensation plans. Jolls (1998), Fenn and Liang (2001) and Weisbenner (2000) point out that firms have incentives to buy back shares to avoid dilution when employee stock options are exercised. This motivation has seemingly grown in importance in recent years as incentive stock options plans assumed an increasing component of compensation in the 1990s. The evidence in Tables 1 through 4 provides some insight as to whether stock options may be a factor in High DA cases. The stock returns of High

${ }^{19}$ When we focus more narrowly on High-L and High-H firms, High-L firms actually show decrease in cash $(-0.76 \%$ with t-statistics of -1.63$)$ whereas High-H firms display some increase in cash $(0.53 \%$ with t-statistics of 1.31). However, this decrease in cash for High-L appears to be caused not by an intentional decision to disgorge cash, but instead (given the results in Table 5 and 6) appears to be driven by a significant drop in operating performance during the year one. 
DA firms during year -1 are very poor. The average raw return was $-11.5 \%$ and even more dramatic -21.9\% for High-L firms. As such, outstanding employee options in these firms are becoming less in-the-money. Stated differently, managers in High DA firms would seemingly have less reason to worry about dilution from a flurry of option exercises in the near future when performance is so poor. One might argue though that due to negative returns, managers might have thought that it would be a "good time” to buy back shares for the purpose of preventing future dilution. This, however, assumes that managers think their shares are undervalued or have foresight that a rebound in performance is pending. Of course, none of this is supported by the long-run performance evidence of low earnings quality firms. In addition, the actual buyback activity of High DA firms presented earlier also shows that they tend to buy back significantly fewer shares than others. ${ }^{20}$

In sum, firms buy back stock for a variety of reasons that are well supported in the economic literature. In this study, we have focused attention on High DA firms arguing that this may proxy for a sub-set of managers who may be under pressure to lift share prices and, thus, may be using a buyback announcement as a low-cost method to mislead investors. Clearly, our proxy is noisy and while one cannot completely rule out that managers in High DA firms might also be responding at the margin to some conventional economic motivation such as leverage or dilution, by the same token it is also hard to rule out the manipulation hypothesis. To this point, our robustness checks have been univariate in nature. As a final check in the next section, we consider these factors together in a multivariate framework.

\subsection{Regression analysis}

In this section, we return back to the abnormal stock return evidence and make one last check to see if the relatively lower return performance of High DA firms can somehow be explained by some factor other than the manipulation hypothesis. To do this, we consider a multivariate environment similar to that reported in Chan, Ikenberry and Lee (2004). They evaluate long-run abnormal stock returns in the context of the free cash flow, leverage, and undervaluation hypotheses. According to the manipulation story, the performance of repurchasing firms with low earnings quality is likely to be lower compared to other firms unless some other value-enhancing, economic factor is present. While we did observe this in a univariate setting, we now re-examine this in a multivariate framework by regressing long-run abnormal

\footnotetext{
${ }^{20}$ One can contend that the results in Table 3 are inconsistent with the argument described here. However, there are two points that make the above argument more compelling. First, the results in Table 3 show that high DA firms' executives exercise their options more than other firms during year -1 but not during year +1 . In addition, the amount of unexercised vested option held by executives in high DA firms is not significantly greater than other firms during year +1 . This indicates that high DA firms are not more concerned about the future dilution from executive option exercises at the buyback announcement compared to others. Second, the amount of executive options is only about one-third of that of total employee stock options (based on the numbers in Kahle (2002)). Therefore, the argument purely based on the executive stock options is missing the main point behind the dilution story. Considering the difficulties of getting employee stock option data, the argument based on the moneyness seems to be more compelling.
} 
four-year returns (at the firm level) on DA quintile values or a dummy for the highest DA quintile (or a dummy for High-L firms) along with other independent variables, market capitalization, B/M ratio, cash, leverage, the size of the repurchase program, the prior one-year abnormal return and the actual buyback amount.

We see in Table 9 that for models one through four, the coefficient on DA quintile is significantly negatively correlated with the long-run abnormal returns, even after controlling for various factors. The same is also true if we use a simple dummy denoting firms in the highest DA quintile. In model seven, these other factors do not explain away the poor performance of firms reporting both high accruals and poor pre-announcement returns (i.e., High-L firms), the cases where concern over possible manipulation is highest. Similar to the results reported in Chan, Ikenberry and Lee (2004), long-run abnormal stock returns are significantly positively related to firm size, the percentage of shares announced to repurchase, and actual buyback amounts. ${ }^{21}$ The findings with respect to leverage are also consistent with their work. While buyback firms generally have low leverage, firms with low leverage do not show higher long-run returns, a result inconsistent with the leverage story.

Regarding the impact of actual buyback activity, the coefficient on this variable in models one and two suggests that significantly higher long-run performance is associated with actual buybacks. In models three through six where we interact actual buyback activity with a High DA dummy, we see marginally significant positive effects; the positive effect of actual buyback activity is significantly greater for high DA firms, and the coefficients of High DA dummy remain significantly negative. When we substitute the High-L dummy for the High DA dummy in model seven, we see similar results; we observe high significance for the High-L dummy and for the interactive variable with actual buyback activity. Given that our sort on DA is a noisy metric of managerial intentions to mislead, this finding is seemingly consistent with the manipulation story; High DA firms, especially High-L firms, where managers announce a program but do not follow through with actual purchase show poorer long-run performance. Managers who are under pressure to repurchase stock due to a slump in performance, even after using accounting conventions to support earnings, cannot benefit shareholders in the long-run simply by announcing a buyback program without intending to actually buy stock.

\section{Summary and conclusion}

Previous academic studies have theorized and empirically examined a number of economic factors

${ }^{21}$ Due to how the free cash flow hypothesis is examined, the results here differ from that reported in Chan, Ikenberry and Lee (2004). If instead we use their definition of free cash flow based on Lehn and Poulsen (1989), free cash flow becomes a significant variable in the regression. Yet even with this alternative definition of free cash flow, our conclusions do not change; the significance of DA and DA-related variables remains significant. 
as to why firms repurchase stock. These include responding to undervaluation, disgorgement of free cash flows, serving as a dividend substitute, altering capital structure, providing a defense against a hostile takeover and prevention of dilution related to employee stock options. On the other hand, surveys of executives also seem to indicate that "price support" is an important reason why firms use share repurchases. Further, some academic studies suggest that share repurchases, particularly those on the open market, may not be good signaling devices as they may afford managers a cheap way to mimic a signal if the costs for falsely announcing a buyback are low. The market, on average, reacts positively to the announcement of open market share repurchases yet, by design, these programs are not binding and are structured for flexibility. As such, these programs afford managers the ability to authorize a buyback even though there is no intention to buy back stock, thus creating the potential for cheap talk (e.g., Bhattacharya and Dittmar (2004)) and the possibility that some announcements are used in a manipulative manner.

While several studies report evidence consistent with key economic motives such as undervaluation, this paper considers whether manipulation of investor expectations may be a primary factor in a sub-set of repurchase announcements where managers may be under pressure to otherwise support stock prices. We do this by focusing on firms with low earnings quality. Previous studies document that managers appear to be using accruals, especially discretionary accruals (DAs), to increase reported earnings in an attempt to manipulate stock prices. To the extent that these attempts to manage earnings are not successful, managers may need to turn to other devices to boost stock prices. In such a case, open market share repurchase programs may serve as an inexpensive means to send a false signal to the market to manipulate expectations.

Using 7,725 programs announced between 1980 and 2000, we find that manipulation may explain why some firms with low earnings quality announce a buyback, especially those with poor prior stock returns. We find that management in high DA firms seem to have strong motive to falsely signal. Not only are these executives making discretionary accounting decisions to support their earnings, but information in the market place is also generally negative prior to a buyback announcement. Although earnings are not falling per se, sales, cash flows adjusted for accruals and returns are suffering. Analysts are revising their earnings downward and the market reaction to quarterly earnings announcements is negative in high DA firms prior to a buyback announcement.

As Sloan (1996) argues, investors may fixate on accounting earnings without paying much attention to the quality of the accounting numbers. Consistent with this and other studies about investor recognition of accruals, we find that initially the market does not seem to pay attention to earnings quality when buyback programs are first announced. The significantly positive announcement period abnormal return indicates that the market initially welcomes the share repurchase decision made even by those 
firms with poor earnings quality. However, the long-term stock return and operating performance suggest that the firms with poor earnings quality behave differently from the general case.

Consistent with previous studies, we observe positive long-term abnormal performance for those repurchasing firms with high earnings quality. Yet, the stock returns of firms with low earnings quality do not outperform in the long-run. The operating performance of these firms shows clear evidence of deterioration after the announcement. When low earnings quality firms are sub-divided into two groups based on the prior quarterly abnormal stock returns, poor performance (generally speaking) is more profound in firms seemingly under greater pressure to manipulate investor perception.

The results are consistent with the notion that in contrast to many of the traditional economic motives in the literature, manipulation may be an important factor motivating managers in some cases. Bad model problems do not seem to explain these results nor, on more careful examination, do previously documented popular motivations explain the results we find for low earnings quality firms.

The evidence, at least for firms that use aggressive accounting practices, suggests that managers when announcing these buybacks may have been motivated to mislead investors. While one cannot rule out hubris as a possible motive, this too would not seem to hold. Clearly prices are falling and managers might defensively be buying back stock if hubris were an important factor. On the other hand, their behavior is generally not so consistent with this story. For example, we find greater option exercise activity in these firms prior to the repurchase announcement and actual buyback activity in the first year of the program is lower than otherwise expected if hubris was an important factor in these cases.

One might wonder that if some repurchases are manipulative in intent, why it is that the market does not penalize these stocks. While low earnings quality firms do not show positive abnormal long-run return performance (a result which is in contrast to the more general case), by the same token these firms do not show evidence of a negative drift. However, the magnitude of the initial announcement for all firms (including high DA firms) is small, roughly 2\%. Even when corrected later, a price change of this magnitude is difficult to distinguish when estimating abnormal long-term stock returns.

Moreover, the fact that some firms may be misleading the market through these programs may provide some insight into why, more generally, we see investors react with skepticism to buyback announcements. If investors cannot, ex-ante, sort through this potentially mis-leading behavior, this might provide some rationale as to why underreaction is often observed in empirical studies of corporate transactions. In the general case, the market seems to slowly correct this underreaction as better information arrives over time, resulting in positive information shocks and long-term abnormal return performance. Yet for low earnings quality firms, managers do not seem to make buyback announcements in advance of any follow-up good news. To the extent that these stocks are fairly valued at the time of the buyback announcement, one should not anticipate a negative return drift. 
Clearly, while previous studies provide strong evidence in support of many of the traditional economic stories used to motivate share repurchases, this paper finds some evidence that at least some open market buyback programs may be intended to manipulate investor opinion. 


\section{References}

Barber, B.M., Lyon, J.D., 1996. Detecting abnormal operating performance: The empirical power and specification of test statistics. Journal of Financial Economics 41, 359-399.

Barber, B.M., Lyon, J.D., 1997. Detecting long-run abnormal stock returns: the empirical power and specification of test statistics. Journal of Financial Economics 43, 341-372.

Barclay, M.J., Smith, Jr., C.W., 1988. Corporate payout policy: Cash dividends versus open-market repurchases. Journal of Financial Economics 22, 61-82.

Beneish, M.D., Vargus, M.E., 2002. Insider trading, earnings quality, and accrual mispricing. Accounting Review 77, 755-791.

Bhattacharya, U., Dittmar, A., 2004. Costless versus costly signaling: Theory and evidence. Working paper, Indiana University.

Blume, M.E., Stambaugh, R.F., 1983. Biases in computed returns: An application to the size effect. Journal of Financial Economics 12, 387-404.

Brav, A., 2000. Inference in long-horizon event studies: A Bayesian approach with application to initial public offerings. Journal of Finance 55, 1979-2016.

Brav, A., Geczy, C., Gompers, P. A., 2000. Is the abnormal return following equity issuances anomalous? Journal of Financial Economics 56, 403-416.

Brav, A., Graham, J. R., Harvey, C. R., Michaely, R., 2005. Payout policy in the $21^{\text {st }}$ century. Journal of Financial Economics 77, 483-527.

Carhart, M.M., 1997. On persistence in mutual fund performance. Journal of Finance 52, 57-82.

Chan, K., Chan, L.K.C., Jegadeesh, N., Lakonishok, J., 2004. The accrual effect in stock returns. Journal of Business, forthcoming.

Chan, K., Ikenberry, D., Lee, I., 2004. Economic sources of gain in share repurchases. Journal of Financial and Quantitative Analysis 39, 461-479.

Clark, J., Dunbar, C., Kahle, K., 2004. The long-run performance of secondary equity issues: A test of the windows of opportunity hypothesis. Journal of Business 77, 575-603.

Comment, R., Jarrell, G.A., 1991. The relative signaling power of Dutch-auction and fixed-price self-tender offers and open-market share purchases. Journal of Finance 46, 1243-1271.

Conard, J., Kaul, G.., 1993. Long-term market overreaction or biases in computed returns. Journal of Finance 48, 39-63.

Dechow, PM, Ge, W., 2005, The persistence of earnings and cash flows and the role of special items: Implications for the accrual anomaly. Working paper, University of Michigan.

Dittmar, A.K., 2000. Why do firms repurchase stock? Journal of Business 73, 331-355. 
Eberhart, A. C., Maxwell, W. F., Siddique, A. R., 2004. An examination of long-term abnormal stock returns and operating performance following R\&D increases. Journal of Finance 59, 623-650.

Fama, E.F., 1998. Market efficiency, long-term returns, and behavioral finance. Journal of Financial Economics 49, 283-306.

Fama, E.F., French, K.R., 1992. The cross-section of expected returns. Journal of Finance 47, 427-466.

Fama, E.F., French, K.R., 1993. Common risk factors in the returns on stocks and bonds. Journal of Financial Economics 33, 3-56.

Fama, E.F., French, K.R., 1996. Multifactor explanations of asset pricing anomalies. Journal of Finance $51,55-84$.

Fama, E.F., French, K.R., 1997. Industry cost of equity. Journal of Financial Economics 43, 153-193.

Fenn, G.W., Liang, N., 2001. Corporate payout policy and managerial stock incentives. Journal of Financial Economics 60, 45-72.

Grullon, G., Ikenberry, D., 2000. What do we know about share repurchases? Journal of Applied Corporate Finance 13, 31-51.

Grullon, G., Michaely, R., 2002. Dividends, share repurchases, and the substitution hypothesis. Journal of Finance 57, 1649-1684.

Grullon, G., Michaely, R., 2004. The information content of share repurchase programs. Journal of Finance 59, 651-680.

Hand, John R. M., 1990, A test of the extended functional fixation hypothesis. The Accounting Review 65,740-763.

Ikenberry, D., Lakonishok, J., Vermaelen, T., 1995. Market underreaction to open market share repurchases. Journal of Financial Economics 39, 181-208.

Ikenberry, D., Lakonishok, J., Vermaelen, T., 2000. Open market stock repurchases: The Canadian experience. Journal of Finance 55, 2373-2397.

Ikenberry, D., Ramnath, S., 2002. Underreaction to self-selected news events: The case of stock splits. Review of Financial Studies 15, 489-526.

Ikenberry, D., Vermaelen, T., 1996. The option to repurchase stock. Financial Management 25, 9-24.

Jain, B. A. and Kini, O., 1994. The post-issue operating performance of IPO firms. Journal of Finance 49, 1699-1726.

Jegadeesh, N., Titman, S., 1993. Returns to buying winners and selling losers: Implications for stock market efficiency. Journal of Finance 48, 65-91.

Jensen, M. C., 2005. The Puzzling State of Low-Integrity Relations Between Managers and Capital Markets. PDF file of slides, http://ssrn.com/abstract=783604. 
Jolls, C., 1998. Stock repurchases and incentive compensation, Working Paper, NBER.

Jones, J., 1991. Earnings management during import relief investigation. Journal of Accounting Research 29, 193-228.

Kahle, K. M., 2002. When a buyback isn't a buyback: open market repurchases and employee options. Journal of Financial Economics 63, 235-261.

Kothari, S., Leone, A., Wasley, C., 2005. Performance matched discretionary accrual measures. Journal of Accounting and Economics 39, 163-197.

Lakonishok, J., Shleifer, A., Vishny, R.W., 1994. Contrarian investment, extrapolation, and risk. Journal of Finance 49, 1541-1578.

Lee, I., 1997. Do firms knowingly sell overvalued equity? Journal of Finance 52, 1439-1466.

Lehn, K., Poulsen, A., 1989. Free cash flow and stockholder gains in going private transactions. Journal of Finance 44, 771-787.

Loughran, T., Ritter, J.R., 1996. Long-term market overreaction: The effect of low-priced stocks. Journal of Finance 51, 1959-1970.

Loughran, T., Ritter, J.R., 1997. The operating performance of firms conducting seasoned equity offerings. Journal of Finance 52, 1823-1850.

Lyon, J.D., Barber, B.M., Tsai, C., 1999. Improved methods for tests of long-run abnormal stock returns. Journal of Finance 54, 165-201.

Massa, M., Rehman, Z., Vermaelen, T., 2005. Mimicking repurchases. Working paper, INSEAD.

Mitchell, M.L., Stafford, E., 2000. Managerial decisions and long-term stock price performance. Journal of Business 73, 287-329.

Oded, J., 2005. Why do firms announce open-market repurchase programs? Review of Financial Studies $18,271-300$.

Ofek, E., Yermack, D., 2000. Taking stock: Equity-based compensation and the evolution of managerial ownership. Journal of Finance 55, 1367-1384.

Peyer, U, Vermaelen, T., 2005. The nature and persistence of buyback anomalies, June 2005, Working paper, INSEAD.

Sloan, R.G., 1996. Do stock prices fully reflect information in accruals and cash flows about future earnings? Accounting Review 71, 289-315.

Stephens, C.P., Weisbach, M.S., 1998. Actual share reacquisitions in open market repurchase programs. Journal of Finance 53, 313-334.

Teoh, S.H., Welch, I., Wong, T.J., 1998. Earnings management and the underperformance of seasoned equity offerings. Journal of Financial Economics 50, 63-99. 
Vermaelen, T., 1981. Common stock repurchases and market signaling. Journal of Financial Economics 9, 139-183.

Weisbenner, S., 2000. Corporate share repurchases in the 1990s: What role do stock options play? Working paper, University of Illinois.

Xie, H., 2001. The mispricing of abnormal accruals, Accounting Review 76, 357-373. 


\section{Appendix}

\subsection{Event-time, buy-and-hold abnormal returns}

We focus much of our evaluation on buy-and-hold abnormal returns. While a conventional cumulative abnormal return (CAR) approach is straightforward to estimate, it implicitly assumes frequent rebalancing and thus implies high transaction costs. Further, while we eliminate sample firms whose price is below $\$ 3$ per share, frequent rebalancing does induce an upward return bias due to bid-ask bounce (Blume and Stambaugh (1983) and Conard and Kaul (1993)).

We calculate annual BHRs for each firm in our sample for the year before and the four years following the repurchase announcement, where each year is defined as 252 trading days. For each event year, portfolio returns are computed based on BHRs of sample firms, assuming an equal-weighted investment strategy. Longer horizon portfolio returns are obtained by compounding annual portfolio returns across event times. This implicitly assumes annual rebalancing and reduces the possibility of any one firm dominating the portfolio in later years.

We follow Lee (1997) and Chan, Ikenberry and Lee (2004) to estimate abnormal return performance using five matching firms. These control firms are formed on the basis of market-cap and book-to-market ratio (B/M), two important factors that explain cross-sectional stock returns (e.g., Fama and French (1992, 1993, and 1996) and Lakonishok, Shleifer, and Vishny (1994)). To identify matching firms for a given repurchase firm, among firms that are in the same size decile as the repurchasing firm, we choose five firms with the closest $\mathrm{B} / \mathrm{M}$ ratios. The abnormal return is obtained by subtracting the matching firm portfolio return from the repurchasing portfolio return.

For statistical inferencing, we employ bootstrapping to get empirical $p$-values as recommended by Lyon, Barber and Tsai (1999). Specifically, we randomly replace each sample firm with another firm with the same size and B/M group at the time of the repurchase announcement, and thus form a "pseudo" portfolio. We calculate BHRs and then abnormal BHRs for this particular portfolio as if it is our sample portfolio. We repeat this process for 1,000 times to form an empirical distribution of abnormal returns. The statistical significance of the sample portfolio abnormal performance is measured by the empirical $p$-value, the fraction of the distribution of pseudo abnormal returns that are greater than that of the original sample abnormal return.

\subsection{Calendar-time abnormal returns derived from factor models}

In each month during our sample period, we form a portfolio of repurchase firms that have announced share repurchases over the past four-year period and then compute the portfolio return.

We reform the portfolio every month. As a result, a time series of portfolio returns is available to run the four-factor model (Carhart (1997)) regressions as follows:

$$
R_{p, t}-R_{f, t}=\alpha+\beta\left(R_{m, t}-R_{f, t}\right)+s S M B_{t}+h H M L_{t}+w W M L_{i}+e_{t}
$$


where $R_{p}$ is the sample firm portfolio return, $R_{f}$ is the risk-free rate, $R_{m}$ is the market portfolio return, SMB is the small-firm portfolio return minus big-firm portfolio return, $H M L$ is the high book-to-market portfolio return minus low book-to-market portfolio return, and WML is the winner portfolio return minus loser portfolio return. SMB and $H M L$ are used to control size and book-to-market effects, respectively. WML is added to incorporate the momentum effect documented by Jegadeesh and Titman (1993). The abnormal returns of repurchase firms can be tested based on the $t$-value of the regression intercept.

Previous studies argue that the abnormal performance (if any) of corporate events occurs in small stocks only (Fama (1998), Mitchell and Stafford (2000) and Brav, Geczy, and Gompers (2000)). Therefore, for robustness checks, we perform the calendar-time portfolio approach by both equally- and log-value-weighting the repurchase sample.

One of our objectives is to examine the relationship between long-run performance of repurchase firms and their earnings quality (proxied by DA quintile ranking). However, any relationship we find could be the manifestation of the DA effect documented in earlier studies. For example, Xie (2001) and Chan, Chan, Jegadeesh and Lakonishok (2004) show that DA is reliably negatively related to future stock returns, and the return predictability of accruals found in Sloan (1996) mainly comes from the discretionary component of accruals.

To control for this DA effect in non-repurchase firms, we modify the factor model regressions by adding an earnings quality factor into the Carhart four-factor model as shown in equation (A2):

$$
R_{p, t}-R_{f, t}=\alpha+\beta\left(R_{m, t}-R_{f, t}\right)+s S M B_{t}+h H M L_{t}+w W M L_{i}+g G M B_{t}+e_{t}
$$

where GMB is the return to the good earnings quality portfolio return minus that of the bad earnings quality portfolio return and the others are defined the same as those in equation (A1). The earnings quality factor is constructed as follows. We first search all firms, covered in both CRSP and Compustat, with available accounting accruals. We run Jones (1991) regressions (based on equation (2)) in order to estimate their DA (based on equation (3)). At the end of June of year t, we sort all these firms into DA quintiles based on the DAs of the fiscal year ending in year $t-1$, and keep track of their next 12 month returns. The earnings quality factor is the median return of the lowest DA quintile (good quality) portfolio minus the median return of the highest DA quintile (bad quality) portfolio.

To apply this five-factor model, in each month, we form a portfolio that is composed of firms that have announced share repurchases within the past four-year period. We start the portfolio formation from 1983 and stop in 2000 even though our sample period starts from 1980. This is to make sure that the portfolio used in the regression analysis is seasoned. We exclude the calendar month with less than sixty firms in the portfolio. We check the sensitivity of the results using different exclusion criteria but the results were qualitatively similar. The portfolio returns are calculated using both equal-weights and 
$\log$ value-weights to check the sensitivity of the results. We use log value-weights, rather than value-weights, to reduce dominating effects of extremely large firms as indicated in Ikenberry and Ramnath (2002). 


\section{Table 1}

\section{Summary Statistics}

This table reports the summary statistics of 7,725 open-market share repurchases during 1980 and 2000, except the fourth quarter of 1987. Each sample firm is required to have accounting accruals at least four months prior to the repurchase announcement. $N$ is the number of announcements. 5-day $A R$ is the repurchase announcement return measured over the 5-day window $(-2,2)$ minus the corresponding CRSP value-weighted index return. REP-1 and MAT-1 are average raw returns over the one-year period prior to the announcement of share repurchases for repurchasing firms and size-and-BM matched control firms, respectively. $A R-1$ is the difference between REP-1 and MAT-1. \% shares announced is the percentage of shares announced to buy back relative to total outstanding shares. Accruals are defined as changes in non-cash current assets, minus changes in current liabilities excluding short-term debt and taxes payable, and minus depreciation. DA is the discretionary accruals based on Jones (1991), which is the residual of the following regression.

$$
\frac{\text { Accruals }_{i}}{T A_{i}}=a_{0} \frac{1}{T A_{i}}+a_{1} \frac{\Delta \text { Sales }_{i}}{T A_{i}}+a_{2} \frac{P P E_{i}}{T A_{i}}+\varepsilon_{i} .
$$

Size quintile (1 is the smallest) is based on the market value of equity of repurchase firm at the month-end prior to the announcement relative to all NYSE firms. BM quintile (1 is the smallest) is based on the ratio of the book value to the market value of equity. DA quintile (1 is the smallest) is the DA quintile ranking relative to all stock universe. Panel A reports summary statistics sorted by years, while Panel B reports results based on DA quintiles. The rows of "Low-High" test the differences between the top and bottom DA quintiles. Numbers in the parentheses are $t$-statistics. High- $L(H i g h-H)$ represents the highest DA quintile with prior one-quarter abnormal return that is below (above) the average prior one-quarter abnormal return of the highest DA quintile firms.

\begin{tabular}{|c|c|c|c|c|c|c|c|c|c|c|c|c|c|}
\hline \multicolumn{14}{|c|}{ Panel A: By year } \\
\hline Year & $\mathrm{N}$ & 5-day AR & REP -1 & \multicolumn{2}{|c|}{ MAT -1 } & \multicolumn{2}{|c|}{ AR-1 } & \multicolumn{2}{|c|}{ \% shares } & DA & $\begin{array}{c}\text { Size } \\
\text { quintile }\end{array}$ & $\begin{array}{c}\mathrm{B} / \mathrm{M} \\
\text { quintile }\end{array}$ & $\begin{array}{c}\text { DA } \\
\text { quintile }\end{array}$ \\
\hline $1980-1990$ & 1739 & $2.23 \%$ & $4.12 \%$ & 11.1 & & -7.0 & & 7.94 & & 0.0033 & 3.40 & 2.80 & 3.03 \\
\hline $1991-2000$ & 5986 & $1.67 \%$ & $1.13 \%$ & 15.3 & & -14.1 & & 7.31 & & -0.0036 & 2.81 & 2.79 & 3.04 \\
\hline All & 7725 & $1.79 \%$ & $1.80 \%$ & 14.3 & & -12.5 & & 7.45 & & -0.0020 & 2.95 & 2.80 & 3.04 \\
\hline \multicolumn{14}{|c|}{ Panel B: By discretionary accruals quintile ranking } \\
\hline DA quintile & $\mathrm{N}$ & 5-day AR & REI & & $\mathrm{M} A$ & -1 & $\mathrm{AF}$ & -1 & $\%$ & hares & DA & $\begin{array}{c}\text { Size } \\
\text { quintile }\end{array}$ & $\begin{array}{c}\mathrm{B} / \mathrm{M} \\
\text { quintile }\end{array}$ \\
\hline Low & 1032 & $2.35 \%$ & 7.1 & & & $52 \%$ & -10 & $33 \%$ & & $59 \%$ & -0.1702 & 2.63 & 2.73 \\
\hline 2 & 1798 & $1.74 \%$ & 7.7 & & & $76 \%$ & & $97 \%$ & & $37 \%$ & -0.0391 & 3.07 & 2.66 \\
\hline 3 & 1936 & $1.46 \%$ & 3.1 & & & $84 \%$ & -11 & $.71 \%$ & & $25 \%$ & 0.0000 & 3.33 & 2.79 \\
\hline 4 & 1751 & $1.70 \%$ & 0.1 & & & $57 \%$ & -11 & $39 \%$ & & $35 \%$ & 0.0371 & 2.96 & 2.90 \\
\hline High & 1208 & $2.06 \%$ & -11. & $49 \%$ & & $01 \%$ & -21 & $.50 \%$ & & $88 \%$ & 0.1369 & 2.41 & 2.92 \\
\hline Low - High & & $\begin{array}{l}0.30 \% \\
(0.69) \\
\end{array}$ & $\begin{array}{r}18.6 \\
(9 .\end{array}$ & $\begin{array}{l}8 \% \\
8 \%) \\
48\end{array}$ & & $\begin{array}{l}1 \% \\
80)\end{array}$ & & $\begin{array}{l}17 \% \\
64) \\
\end{array}$ & & $\begin{array}{l}29 \% \\
.85) \\
\end{array}$ & $\begin{array}{l}-0.3071 \\
(-11.44) \\
\end{array}$ & $\begin{array}{c}0.23 \\
(4.00) \\
\end{array}$ & $\begin{array}{c}-0.19 \\
(-3.44)\end{array}$ \\
\hline High-L & 600 & $2.29 \%$ & -21. & $1 \%$ & & $27 \%$ & -40 & $19 \%$ & & $47 \%$ & 0.1368 & 2.35 & 2.69 \\
\hline High-H & 608 & $1.83 \%$ & -1.2 & $0 \%$ & & $5 \%$ & -3. & $05 \%$ & & $29 \%$ & 0.1370 & 2.46 & 3.15 \\
\hline
\end{tabular}




\section{Table 2 \\ Quarterly Earnings Announcement Returns and Analysts’ Forecast Revisions}

This table presents the quarterly earnings announcement returns (in \%) and analysts' forecast revisions (in \%) prior to repurchase announcement for the bottom and top DA quintiles. Panel A reports the earnings announcement return defined as the buy-and-hold return compounded from day -2 to +2 relative to the quarterly earnings announcement date minus the CRSP value-weight index return over the same interval. Extreme abnormal return observations above $20 \%$ or below $-20 \%$ are eliminated. Quarter -1 represents the quarter with earnings announcement date right before the repurchase announcement. Numbers in Panel A are mean returns, and numbers in brackets are median returns, and the number in the third row of each cell is the number of observations. Panel B reports proportions of firms with negative abnormal forecast revisions. Forecast revision at quarter -1 indicates the result for monthly forecast revisions during the 3 months right before repurchase announcements. The abnormal forecast revision equals the forecast revision minus the expected forecast revision, where the expected forecast revision equals the average change in analysts' earnings forecasts during all months available at the IBES data but excluding the months -6 to 6 around the month end of the calculation. The rows of "Low-High" show the differences between the top and bottom DA quintiles. ${ }^{* * *}, * *$, and $*$ indicate the significance level of $1 \%, 5 \%$, and $10 \%$, respectively. High- $L$ $(H i g h-H)$ represents the highest DA quintile with prior one-quarter abnormal return that is below (above) the average prior one-quarter abnormal return of the highest DA quintile firms. All numbers in Panel B are based on analysts' average EPS forecast revisions, and numbers in brackets are based on median forecast revisions.

\begin{tabular}{|c|c|c|c|c|}
\hline \multirow{2}{*}{ DA quintiles } & \multicolumn{4}{|c|}{ Event Quarters } \\
\hline & -4 & -3 & -2 & -1 \\
\hline \multicolumn{5}{|c|}{ Panel A: Earnings announcement return } \\
\hline Low & $\begin{array}{c}0.628^{* * * *} \\
{\left[0.444^{* * *}\right]} \\
880\end{array}$ & $\begin{array}{c}0.338 \\
{[0.258]} \\
895\end{array}$ & $\begin{array}{c}0.020 \\
{[-0.147]} \\
899\end{array}$ & $\begin{array}{c}-0.113 \\
{[-0.166]} \\
904\end{array}$ \\
\hline High & $\begin{array}{c}0.302 \\
{[-0.124]} \\
1023\end{array}$ & $\begin{array}{c}0.172 \\
{[-0.024]} \\
1045\end{array}$ & $\begin{array}{c}0.021 \\
{[-0.162]} \\
1055\end{array}$ & $\begin{array}{c}-0.993^{* * *} \\
{\left[-0.996^{* * *}\right]} \\
1049\end{array}$ \\
\hline Low - High & $\begin{array}{c}0.326 \\
{[0.568]}\end{array}$ & $\begin{array}{c}0.166 \\
{[0.282]}\end{array}$ & $\begin{array}{c}-0.001 \\
{[0.016]}\end{array}$ & $\begin{array}{c}0.879^{* * *} \\
{\left[0.830^{* * *}\right]}\end{array}$ \\
\hline High-L & $\begin{array}{c}0.361 \\
{[-0.063]} \\
480\end{array}$ & $\begin{array}{c}0.252 \\
{[0.255]} \\
485\end{array}$ & $\begin{array}{c}-0.420 \\
{[-0.396]} \\
480\end{array}$ & $\begin{array}{c}-2.352^{* * *} \\
{\left[-2.182^{* * *}\right]} \\
475\end{array}$ \\
\hline High- $\mathrm{H}$ & $\begin{array}{c}0.250 \\
{[-0.278]} \\
543\end{array}$ & $\begin{array}{c}0.102 \\
{[-0.297]} \\
560\end{array}$ & $\begin{array}{c}0.390 \\
{[0.034]} \\
575\end{array}$ & $\begin{array}{c}0.132 \\
{[0.034]} \\
574\end{array}$ \\
\hline \multicolumn{5}{|c|}{ Panel B: Proportion of negative abnormal forecast revisions } \\
\hline Low & $\begin{array}{c}50.91 \\
{[48.7]}\end{array}$ & $\begin{array}{c}49.05 \\
{[48.29]}\end{array}$ & $\begin{array}{c}51.88 \\
{[51.01]}\end{array}$ & $\begin{array}{c}54.59 \\
{[55.46 \text { ] }}\end{array}$ \\
\hline High & $\begin{array}{c}53.23 \\
{[51.96]}\end{array}$ & $\begin{array}{c}50.50 \\
{[50.83 \text { ] }}\end{array}$ & $\begin{array}{c}56.56 \\
{[55.91]}\end{array}$ & $\begin{array}{c}60.08 \\
{[59.56 \text { ] }}\end{array}$ \\
\hline Low - High & $\begin{array}{c}-2.32 \\
{[-3.27]}\end{array}$ & $\begin{array}{c}-1.45 \\
{[-2.54]}\end{array}$ & $\begin{array}{c}-4.67^{* *} \\
{\left[-4.91^{* * *}\right]}\end{array}$ & $\begin{array}{l}-5.49^{* * *} \\
{\left[-4.10^{*}\right]}\end{array}$ \\
\hline High-L & $\begin{array}{c}51.41 \\
{[50.47]}\end{array}$ & $\begin{array}{c}48.21 \\
{[49.10]}\end{array}$ & $\begin{array}{c}51.52 \\
{[50.43]}\end{array}$ & $\begin{array}{c}60.04 \\
{[60.25]}\end{array}$ \\
\hline High- $\mathrm{H}$ & $\begin{array}{c}55.00 \\
{[53.41]}\end{array}$ & $\begin{array}{c}52.76 \\
{[52.54]}\end{array}$ & $\begin{array}{c}61.49 \\
{[61.28]}\end{array}$ & $\begin{array}{c}60.13 \\
{[58.86]}\end{array}$ \\
\hline
\end{tabular}




\section{Table 3 \\ Stock Options of Top-Executives}

This table presents the stock options held by CEOs and top-five executives. Two measures are applied. Panel A presents the stock options exercised divided by total shares outstanding, and panel B shows the unexercised vested options divided by total shares outstanding. Year -1 (Year 1) is the calendar year before (of) the year of repurchase announcement. Each measure is with $0.5 \%$ winsorization for top-bottom observations. The rows of "Low-High" test the differences between the top and bottom DA quintiles. High- $L(H i g h-H)$ represents the highest DA quintile with prior one-quarter abnormal return that is below (above) the average prior one-quarter abnormal return of the highest DA quintile firms. Numbers in parentheses are $t$-statistics and numbers in italics are the numbers of observations.

\begin{tabular}{|c|c|c|c|c|c|c|c|c|}
\hline \multirow{3}{*}{ DA quintiles } & \multicolumn{4}{|c|}{$\begin{array}{l}\text { Stock options exercised to } \\
\text { shares outstanding }\end{array}$} & \multicolumn{4}{|c|}{$\begin{array}{l}\text { Unexercised vested options to } \\
\text { share outstanding }\end{array}$} \\
\hline & \multicolumn{2}{|c|}{ For CEOs } & \multicolumn{2}{|c|}{$\begin{array}{l}\text { For top-five } \\
\text { executives }\end{array}$} & \multicolumn{2}{|c|}{ For CEOs } & \multicolumn{2}{|c|}{$\begin{array}{l}\text { For top-five } \\
\text { executives }\end{array}$} \\
\hline & Year-1 & Year1 & Year-1 & Year1 & Year-1 & Year1 & Year-1 & Year1 \\
\hline \multirow{2}{*}{ All } & $0.081 \%$ & $0.078 \%$ & $0.241 \%$ & $0.238 \%$ & $0.528 \%$ & $0.609 \%$ & $1.255 \%$ & $1.370 \%$ \\
\hline & 2007 & 2298 & 2789 & 3021 & 2007 & 2298 & 2789 & 3021 \\
\hline \multirow{2}{*}{ Low } & $0.093 \%$ & $0.065 \%$ & $0.256 \%$ & $0.246 \%$ & $0.451 \%$ & $0.591 \%$ & $1.327 \%$ & $1.522 \%$ \\
\hline & 235 & 279 & 332 & 366 & 235 & 279 & 332 & 366 \\
\hline \multirow{2}{*}{2} & $0.056 \%$ & $0.072 \%$ & $0.233 \%$ & $0.244 \%$ & $0.476 \%$ & $0.563 \%$ & $1.218 \%$ & $1.320 \%$ \\
\hline & 514 & 584 & 689 & 754 & 514 & 584 & 689 & 754 \\
\hline \multirow{2}{*}{3} & $0.057 \%$ & $0.058 \%$ & $0.183 \%$ & $0.186 \%$ & $0.450 \%$ & $0.540 \%$ & $1.081 \%$ & $1.209 \%$ \\
\hline & 599 & 675 & 831 & 883 & 599 & 675 & 831 & 883 \\
\hline \multirow{2}{*}{4} & $0.094 \%$ & $0.113 \%$ & $0.258 \%$ & $0.270 \%$ & $0.644 \%$ & $0.702 \%$ & $1.315 \%$ & $1.409 \%$ \\
\hline & 460 & 521 & 655 & 701 & 460 & 521 & 655 & 701 \\
\hline \multirow{2}{*}{ High } & $0.172 \%$ & $0.085 \%$ & $0.374 \%$ & $0.292 \%$ & $0.721 \%$ & $0.731 \%$ & $1.633 \%$ & $1.679 \%$ \\
\hline & 199 & 239 & 282 & 317 & 199 & 239 & 282 & 317 \\
\hline \multirow{2}{*}{ Low - High } & $-0.079 \%$ & $-0.020 \%$ & $-0.118 \%$ & $-0.046 \%$ & $-0.270 \%$ & $-0.140 \%$ & $-0.306 \%$ & $-0.157 \%$ \\
\hline & $(-1.74)$ & $(-0.94)$ & $(-2.28)$ & $(-1.13)$ & $(-2.65)$ & $(-1.45)$ & $(-2.17)$ & $(-1.17)$ \\
\hline \multirow{2}{*}{ High-L } & $0.286 \%$ & $0.108 \%$ & $0.479 \%$ & $0.322 \%$ & $0.636 \%$ & $0.683 \%$ & $1.616 \%$ & $1.742 \%$ \\
\hline & 99 & 114 & 141 & 155 & 99 & 114 & 141 & 155 \\
\hline \multirow{2}{*}{ High-H } & $0.090 \%$ & $0.064 \%$ & $0.289 \%$ & $0.264 \%$ & 0.819\% & $0.775 \%$ & $1.650 \%$ & $1.618 \%$ \\
\hline & 100 & 125 & 141 & 162 & 100 & 125 & 141 & 162 \\
\hline
\end{tabular}




\section{Table 4}

\section{Long-run Buy-and-hold Returns}

This table presents long-run buy-and-hold abnormal returns (in \%). Panel A presents the results over the full sample period (1980-2000), and panel B shows the results for two sub-periods (1980-1990 and 1991-2000). Annual buy-and-hold returns (BHRs) for individual firms are first calculated by compounding the daily returns of each repurchase firm for 252 days, or up to the delisting date (whichever is earlier). For each event year, portfolio returns are computed based on BHRs of sample firms, assuming an equal-weighted investment strategy. Long-run returns (except event year -1 ) are then obtained by compounding the annual portfolio returns over time, starting from year $1 . N$ is the number of firms in each category. REP refers to the repurchasing firms and MAT refers to the size/BM matching firms. AR represents the abnormal buy-and-hold return, the difference between BHRs of repurchasing and corresponding matching firms. Based on the empirical distribution via bootstrapping, the $p$-value is presented following the abnormal return. In Panel A, High- $L$ (High- $H$ ) represents the highest DA quintile with prior one-quarter abnormal return that is below (above) the average prior one-quarter abnormal return of the highest DA quintile firms.

\begin{tabular}{|c|c|c|c|c|c|c|c|c|c|c|c|c|c|c|c|c|c|c|c|c|c|c|c|c|c|}
\hline \multirow{2}{*}{$\begin{array}{c}\text { DA } \\
\text { rank }\end{array}$} & \multicolumn{5}{|c|}{ Year -1} & \multicolumn{5}{|c|}{ Year 1} & \multicolumn{5}{|c|}{ Year 2} & \multicolumn{5}{|c|}{ Year 3} & \multicolumn{5}{|c|}{ Year 4} \\
\hline & $\mathrm{N}$ & REP & MAT & AR & $p$ & $\mathrm{~N}$ & REP & MAT & AR & $p$ & $\mathrm{~N}$ & REP & MAT & $\mathrm{AR}$ & $p$ & $\mathrm{~N}$ & REP & MAT & AR & $p$ & $\mathrm{~N}$ & REP & MAT & $\mathrm{AR}$ & $p$ \\
\hline \multicolumn{26}{|c|}{ Panel A: Full period } \\
\hline All & 7725 & 1.80 & 14.38 & -12.58 & 1.000 & 7725 & 22.43 & 17.77 & 4.66 & 0.000 & 7468 & 41.97 & 34.43 & 7.55 & 0.000 & 6989 & 64.00 & 53.07 & 10.93 & 0.000 & 6521 & 89.33 & 73.72 & 15.61 & 0.000 \\
\hline Low & 1032 & 7.19 & 17.52 & -10.33 & 0.993 & 1032 & 27.12 & 18.86 & 8.25 & 0.000 & 1003 & 47.68 & 33.47 & 14.21 & 0.000 & 924 & 76.82 & 52.72 & 24.10 & 0.000 & 842 & 105.94 & 69.03 & 36.91 & 0.000 \\
\hline 2 & 1798 & 7.79 & 17.76 & -9.97 & 1.000 & 1798 & 23.38 & 17.15 & 6.23 & 0.000 & 1736 & 44.37 & 34.24 & 10.13 & 0.000 & 1632 & 64.08 & 52.00 & 12.08 & 0.000 & 1531 & 93.76 & 73.57 & 20.19 & 0.000 \\
\hline 3 & 1936 & 3.14 & 14.84 & -11.71 & 1.000 & 1936 & 21.03 & 17.50 & 3.53 & 0.000 & 1884 & 39.88 & 34.29 & 5.59 & 0.000 & 1787 & 61.31 & 51.94 & 9.37 & 0.011 & 1684 & 85.95 & 74.14 & 11.82 & 0.017 \\
\hline 4 & 1751 & 0.17 & 11.57 & -11.39 & 1.000 & 1751 & 21.33 & 18.29 & 3.04 & 0.015 & 1679 & 42.60 & 35.18 & 7.42 & 0.000 & 1560 & 63.41 & 55.40 & 8.01 & 0.000 & 1470 & 83.34 & 75.00 & 8.34 & 0.000 \\
\hline High & 1208 & -11.49 & 10.01 & -21.50 & 1.000 & 1208 & 20.87 & 17.45 & 3.42 & 0.063 & 1166 & 36.07 & 734.65 & 1.42 & 0.119 & 1086 & 58.34 & 53.43 & 4.91 & 0.103 & 994 & 83.00 & 75.25 & 7.75 & 0.116 \\
\hline High-L & 600 & -21.91 & 18.27 & -40.19 & 1.000 & 600 & 16.92 & 18.26 & -1.34 & 0.528 & 578 & 29.07 & 36.64 & +-7.58 & 0.492 & 539 & 47.06 & 55.13 & -8.07 & 0.493 & 487 & 70.84 & 76.63 & -5.79 & 0.509 \\
\hline igh-H & 608 & -1.20 & 1.85 & -3.05 & 0.950 & 608 & 24.77 & 16.66 & 8.12 & 0.008 & 588 & 43.13 & 32.69 & 10.44 & 0.017 & 547 & 69.99 & 51.76 & 18.22 & 0.020 & 507 & 5.48 & 73.86 & 21.62 & 0.044 \\
\hline \multicolumn{26}{|c|}{ Panel B: $1980-1990$} \\
\hline All & 1739 & 4.12 & 11 & -7.01 & 1.000 & 1739 & 23.23 & 17.06 & 6.17 & 0.000 & 1704 & 41.66 & 35.97 & 5.69 & 0.007 & 1651 & 69.32 & 60.66 & 8.66 & 0.009 & 1594 & 90.77 & 79.90 & 10.87 & 0.007 \\
\hline Low & 212 & 10.75 & 12.86 & -2.12 & 0.366 & 212 & 21.41 & 18.14 & 3.27 & 0.178 & 210 & 34.52 & 32.35 & 2.17 & 0.288 & 204 & 71.14 & 57.30 & 13.84 & 0.075 & 201 & 94.01 & 71.29 & 22.72 & 0.048 \\
\hline 2 & 434 & 6.78 & 13.04 & -6.26 & 1.000 & 434 & 24.14 & 17.81 & 6.33 & 0.007 & 425 & 45.51 & 36.40 & 9.10 & 0.008 & 413 & 71.23 & 59.99 & 11.24 & 0.030 & 389 & 97.21 & 81.38 & 15.83 & 0.007 \\
\hline 3 & 444 & 5.90 & 11.33 & -5.43 & 0.991 & 444 & 24.56 & 16.07 & 8.49 & 0.008 & 438 & 43.15 & 34.44 & 8.70 & 0.025 & 425 & 72.79 & 60.05 & 12.74 & 0.016 & 411 & 91.55 & 81.21 & 10.33 & 0.055 \\
\hline 4 & 395 & 2.90 & 10.02 & -7.12 & 0.991 & 395 & 21.79 & 15.67 & 6.12 & 0.010 & 387 & 42.36 & 36.55 & 5.80 & 0.002 & 374 & 70.16 & 61.33 & 8.83 & 0.019 & 363 & 86.95 & 78.38 & 8.57 & 0.080 \\
\hline High & 254 & -7.20 & 7.80 & -15.00 & 1.000 & 254 & 23.13 & 18.79 & 4.34 & 0.026 & 244 & 37.38 & 30.02 & -2.64 & 0.244 & 235 & 56.59 & 64.57 & -7.98 & 0.544 & 230 & 80.81 & 84.80 & -3.99 & 0.403 \\
\hline \multicolumn{26}{|c|}{ Panel C: 1991-2000 } \\
\hline All & 5986 & 1.13 & 15.33 & -14.19 & 1.000 & 5986 & 22.20 & 17.98 & 4.22 & 0.000 & 5764 & 42.07 & 33.96 & 8.10 & 0.000 & 5338 & 62.35 & 50.76 & 11.59 & 0.000 & 4927 & 88.88 & 71.84 & 17.04 & 0.000 \\
\hline Low & 820 & 6.27 & 18.72 & -12.45 & 1.000 & 820 & 28.59 & 19.05 & 9.54 & 0.000 & 793 & 51.23 & 33.16 & 17.47 & 0.000 & 720 & 77.86 & 51.38 & 26.48 & 0.002 & 641 & 108.88 & 68.39 & 40.49 & 0.000 \\
\hline 2 & 1364 & 8.11 & 19.27 & -11.15 & 1.000 & 1364 & 23.14 & 16.95 & 6.20 & 0.008 & 1311 & 44.01 & 33.54 & 10.46 & 0.000 & 1219 & 61.71 & 49.38 & 12.33 & 0.000 & 1142 & 92.57 & 71.00 & 21.57 & 0.000 \\
\hline 3 & 1492 & 2.31 & 15.89 & -13.57 & 1.000 & 1492 & 19.97 & 17.92 & 2.05 & 0.010 & 1446 & 38.90 & 34.23 & 4.67 & 0.009 & 1362 & 57.85 & 49.40 & 8.45 & 0.015 & 1273 & 84.22 & 71.89 & 12.33 & 0.016 \\
\hline 4 & 1356 & -0.62 & 12.02 & -12.64 & 1.000 & 1356 & 21.19 & 19.05 & 2.14 & 0.029 & 1292 & 42.67 & 34.71 & 7.96 & 0.000 & 1186 & 61.27 & 53.50 & 7.77 & 0.000 & 1107 & 82.18 & 73.89 & 8.29 & 0.014 \\
\hline High & 954 & -12.63 & 10.60 & -23.23 & 1.000 & 954 & 20.27 & 17.09 & 3.18 & 0.130 & 922 & 35.71 & - 33.23 & 2.47 & 0.146 & 851 & 58.82 & 50.51 & 8.31 & 0.106 & 764 & 83.60 & 72.78 & 10.82 & 0.132 \\
\hline
\end{tabular}




\section{Table 5 \\ Operating Performance}

This table presents the median operating performance (in \%) around repurchase announcements for the top and bottom DA quintiles. The operating performance is measured by return-on-assets (ROAs) defined as operating income before depreciation divided by average total assets. Year 1 represents the fiscal year of the repurchase announcement. Panel A shows raw ROAs without any adjustment. Panel B presents abnormal ROAs obtained by subtracting matching firm's ROAs from repurchase firm's ROAs. In the same 2-digit SIC-code industry as of repurchase sample firm, we select the matching firm whose pre-event ROA is within $80 \%$ to $120 \%$ or \pm 0.01 of the sample firm's pre-event ROA. If more than one firm satisfies the condition, we choose the firm with closest pre-event ROA as of the sample firm. On the other hand, if no matching firm is found, we then search 1-digit SIC-code industry. If there is still no firm which meets the criterion, we search all possible firms with similar pre-event ROA. Panel C shows the cumulative changes in ROAs, which cumulates the changes in abnormal ROAs starting from year 1. The rows of "Low-High" test the differences between the top and bottom DA quintiles. High- $L$ (High- $H$ ) represents the highest DA quintile with prior one-quarter abnormal return that is below (above) the average prior one-quarter abnormal return of the highest DA quintile firms. Numbers in parentheses are $p$-values based on Wilcoxon median tests.

\begin{tabular}{|c|c|c|c|c|c|}
\hline \multirow{2}{*}{ DA rank } & \multicolumn{5}{|c|}{ Event year } \\
\hline & -1 & 1 & 2 & 3 & 4 \\
\hline \multicolumn{6}{|c|}{ Panel A: Unadjusted ROAs } \\
\hline Low & 16.42 & 16.29 & 15.21 & 14.65 & 14.28 \\
\hline High & 17.55 & 15.06 & 13.06 & 12.67 & 12.41 \\
\hline Lou_High & -1.14 & 1.23 & 2.16 & 1.97 & 1.87 \\
\hline LOW-HIgII & $(0.001)$ & $(0.003)$ & $(0.000)$ & $(0.000)$ & $(0.000)$ \\
\hline High-L & 19.14 & 16.11 & 12.77 & 11.94 & 11.58 \\
\hline High-H & 15.79 & 14.16 & 13.22 & 13.19 & 12.97 \\
\hline \multicolumn{6}{|c|}{ Panel B: Abnormal ROAs } \\
\hline Low & $\begin{array}{c}0.00 \\
(0.016)\end{array}$ & $\begin{array}{c}1.71 \\
(0.000)\end{array}$ & $\begin{array}{c}3.06 \\
(0.000)\end{array}$ & $\begin{array}{c}3.17 \\
(0.000)\end{array}$ & $\begin{array}{c}2.96 \\
(0.000)\end{array}$ \\
\hline High & $\begin{array}{c}0.00 \\
(0.782)\end{array}$ & $\begin{array}{c}-0.86 \\
(0.006) \\
\end{array}$ & $\begin{array}{c}-0.74 \\
(0.269)\end{array}$ & $\begin{array}{c}-0.04 \\
(0.836)\end{array}$ & $\begin{array}{c}-0.08 \\
(0.459) \\
\end{array}$ \\
\hline Low-High & $\begin{array}{c}0.00 \\
(0.045)\end{array}$ & $\begin{array}{c}2.57 \\
(0.000)\end{array}$ & $\begin{array}{c}3.81 \\
(0.000)\end{array}$ & $\begin{array}{c}3.20 \\
(0.000)\end{array}$ & $\begin{array}{c}3.05 \\
(0.000)\end{array}$ \\
\hline High-L & $\begin{array}{c}0.00 \\
(0.745)\end{array}$ & $\begin{array}{c}-1.62 \\
(0.002)\end{array}$ & $\begin{array}{l}-2.30 \\
(0.007)\end{array}$ & $\begin{array}{l}-1.80 \\
(0.090)\end{array}$ & $\begin{array}{c}-1.03 \\
(0.253)\end{array}$ \\
\hline High-H & $\begin{array}{c}0.00 \\
(0.866)\end{array}$ & $\begin{array}{c}-0.17 \\
(0.526) \\
\end{array}$ & $\begin{array}{c}0.37 \\
(0.165) \\
\end{array}$ & $\begin{array}{c}1.20 \\
(0.030) \\
\end{array}$ & $\begin{array}{c}1.13 \\
(0.015) \\
\end{array}$ \\
\hline \multicolumn{6}{|c|}{ Panel C: Cumulative changes in abnormal ROAs } \\
\hline Low & & $\begin{array}{c}1.69 \\
(0.000)\end{array}$ & $\begin{array}{c}3.06 \\
(0.000)\end{array}$ & $\begin{array}{c}3.00 \\
(0.000)\end{array}$ & $\begin{array}{c}3.09 \\
(0.000)\end{array}$ \\
\hline High & & $\begin{array}{c}-0.91 \\
(0.003)\end{array}$ & $\begin{array}{c}-0.81 \\
(0.227)\end{array}$ & $\begin{array}{c}-0.22 \\
(0.965)\end{array}$ & $\begin{array}{c}-0.17 \\
(0.514) \\
\end{array}$ \\
\hline Low-High & & $\begin{array}{c}2.60 \\
(0.000)\end{array}$ & $\begin{array}{c}3.87 \\
(0.000)\end{array}$ & $\begin{array}{c}3.22 \\
(0.000)\end{array}$ & $\begin{array}{c}3.26 \\
(0.000)\end{array}$ \\
\hline High-L & & $\begin{array}{c}-1.57 \\
(0.001)\end{array}$ & $\begin{array}{c}-2.22 \\
(0.006)\end{array}$ & $\begin{array}{c}-1.85 \\
(0.071)\end{array}$ & $\begin{array}{c}-1.09 \\
(0.237)\end{array}$ \\
\hline High-H & & $\begin{array}{c}-0.13 \\
(0.435)\end{array}$ & $\begin{array}{c}0.26 \\
(0.189)\end{array}$ & $\begin{array}{c}1.02 \\
(0.038)\end{array}$ & $\begin{array}{c}1.07 \\
(0.018)\end{array}$ \\
\hline
\end{tabular}




\section{Table 6 \\ Actual Repurchase Activity}

This table presents the actual buyback activity for DA quintiles (Panel A) and Tobit regression results (Panel B). The actual buyback amount is obtained from quarterly cash flow statements on funds used to redeem stock during the first year of repurchase announcement, and adjusted for concurrent changes in preferred stock. $\quad N$ is the number of firms with available actual buyback information. Firms without actual buyback information are excluded from the analysis. Actual Buy is the actual buyback amount divided by average market value of equity. Actual/Intend is the ratio of shares firms actually bought back to shares firms announced to buy back. The rows of "Low-High" test the differences between the top and bottom DA quintiles. ***, **, and * indicate the significance level of $1 \%, 5 \%$, and $10 \%$, respectively. High-L $(H i g h-H)$ represents the highest DA quintile with prior one-quarter abnormal return that is below (above) the average prior one-quarter abnormal return of the highest DA quintile firms. All numbers on top of each cell are mean values, and numbers in the bracket are medians. The dependent variable in Tobit regressions of Panel B is the actual buyback amount relative to market value of equity (in \%). DA quintile (1 is the smallest) is the quintile ranking of DA obtained from the Jones (1991) model. High DA dummy is l for the top DA quintile, and 0 elsewhere. High-L dummy is 1 if a sample firm belongs to the top DA quintile and its one quarter return prior to repurchase announcement is below the average prior one-quarter abnormal return of the highest DA quintile firms, and 0 elsewhere. Size decile ( 1 being the smallest) is based on the market value of equity at the month-end prior to the repurchase announcement. \% shares announced is the percentage of announced repurchase shares relative to total outstanding shares at month-end prior to the announcement. Abnormal announcement return is the difference between the sample firm's compounded five-day return over days -2 to +2 relative to the announcement and the compounded return of the CRSP value-weighted index over the same period. Prior one-year abnormal return is the prior one year buy-and-hold returns compounded from 252 days before (or the listing date) up to three days before the announcement for repurchasing firms minus the compounded return of the matching firms over the same period. $B / M$ quintile ( 1 being the lowest) is based on the ratio of the book equity value at the previous fiscal year-end to total market value at month-end prior to the announcement. CASH quintile is based on the industry median-adjusted cash plus short-term investments over total assets. LEV quintile is based on the industry median-adjusted ratio of the total debt to total assets at the previous fiscal year-end. High BM dummy is 1 for the top BM quintile, and 0 elsewhere. High CASH dummy is 1 for the top CASH quintile, and 0 elsewhere. Low LEV dummy is 1 for the bottom LEV quintile, and 0 elsewhere. Four-year abnormal return is the buy-and-hold return compounded from three days after the announcement date up to the fourth anniversary of announcement date for repurchasing firms minus the compounded return of the matching firms over the same period. Year dummy variables are included, but not reported. Numbers in parentheses are $p$-values.

\begin{tabular}{|c|c|c|c|c|}
\hline \multicolumn{5}{|c|}{ Panel A: Actual buyback ratios } \\
\hline DA rank & $\mathrm{N}$ & Actual Buy & Intend Buy & Actual/Intend \\
\hline All & 6365 & $\begin{array}{c}0.0520 \\
{[0.0325]}\end{array}$ & $\begin{array}{c}0.0745 \\
{[0.0560]}\end{array}$ & $\begin{array}{c}0.5793 \\
{[0.6026]}\end{array}$ \\
\hline Low & 869 & $\begin{array}{c}0.0538 \\
{[0.0356]}\end{array}$ & $\begin{array}{c}0.0759 \\
{[0.0600]}\end{array}$ & $\begin{array}{c}0.5789 \\
{[0.6021]}\end{array}$ \\
\hline 2 & 1482 & $\begin{array}{c}0.0555 \\
{[0.0344]}\end{array}$ & $\begin{array}{c}0.0737 \\
{[0.0559]}\end{array}$ & $\begin{array}{c}0.5954 \\
{[0.6344]}\end{array}$ \\
\hline 3 & 1524 & $\begin{array}{c}0.0493 \\
{[0.0308 \text { ] }}\end{array}$ & $\begin{array}{c}0.0725 \\
{[0.0540 \text { ] }}\end{array}$ & $\begin{array}{c}0.5807 \\
{[0.5896]}\end{array}$ \\
\hline 4 & 1468 & $\begin{array}{c}0.0527 \\
{[0.0329]}\end{array}$ & $\begin{array}{c}0.0735 \\
{[0.0550 \text { ] }}\end{array}$ & $\begin{array}{c}0.5865 \\
{[0.6280]}\end{array}$ \\
\hline High & 1022 & $\begin{array}{c}0.0481 \\
{[0.0301]}\end{array}$ & $\begin{array}{c}0.0788 \\
{[0.0570]}\end{array}$ & $\begin{array}{c}0.5437 \\
{[0.5571]}\end{array}$ \\
\hline Low - High & & $\begin{array}{c}0.0046^{* * *} \\
{\left[0.0055^{* * *}\right]}\end{array}$ & $\begin{array}{c}-0.0030 \\
{[0.0030]}\end{array}$ & $\begin{array}{c}0.0351^{* *} \\
{\left[0.0450^{* *}\right]}\end{array}$ \\
\hline High-L & 511 & $\begin{array}{c}0.0455 \\
{[0.0282]}\end{array}$ & $\begin{array}{c}0.0747 \\
{[0.0554]}\end{array}$ & $\begin{array}{c}0.5343 \\
{[0.5249]}\end{array}$ \\
\hline High-H & 511 & $\begin{array}{c}0.0507 \\
{[0.0330]}\end{array}$ & $\begin{array}{c}0.0829 \\
{[0.0580]}\end{array}$ & $\begin{array}{c}0.5531 \\
{[0.5744]}\end{array}$ \\
\hline
\end{tabular}


Table 6 - Continued

\begin{tabular}{|c|c|c|c|c|c|c|}
\hline \multicolumn{7}{|c|}{ Panel B: Tobit regressions of actual buyback ratio } \\
\hline Model & 1 & 2 & 3 & 4 & 5 & 6 \\
\hline Intercept & $\begin{array}{c}1.178 \\
(0.039)\end{array}$ & $\begin{array}{c}3.315 \\
(0.000)\end{array}$ & $\begin{array}{c}0.830 \\
(0.114)\end{array}$ & $\begin{array}{c}2.985 \\
(0.000)\end{array}$ & $\begin{array}{c}0.664 \\
(0.201)\end{array}$ & $\begin{array}{c}2.966 \\
(0.000)\end{array}$ \\
\hline DA quintile & $\begin{array}{l}-0.144 \\
(0.028)\end{array}$ & $\begin{array}{l}-0.150 \\
(0.022)\end{array}$ & & & & \\
\hline High DA dummy & & & $\begin{array}{l}-0.487 \\
(0.034)\end{array}$ & $\begin{array}{c}-0.541 \\
(0.019)\end{array}$ & & $\begin{array}{l}-0.535 \\
(0.020)\end{array}$ \\
\hline High-L dummy & & & & & $\begin{array}{c}-0.549 \\
(0.074)\end{array}$ & \\
\hline Size decile & $\begin{array}{c}0.081 \\
(0.014)\end{array}$ & $\begin{array}{c}0.016 \\
(0.623)\end{array}$ & $\begin{array}{c}0.074 \\
(0.027)\end{array}$ & $\begin{array}{c}0.008 \\
(0.796)\end{array}$ & $\begin{array}{c}0.081 \\
(0.015)\end{array}$ & $\begin{array}{c}0.005 \\
(0.873)\end{array}$ \\
\hline$\%$ shares announced & $\begin{array}{c}0.259 \\
(0.000)\end{array}$ & $\begin{array}{c}0.264 \\
(0.000)\end{array}$ & $\begin{array}{c}0.259 \\
(0.000)\end{array}$ & $\begin{array}{c}0.264 \\
(0.000)\end{array}$ & $\begin{array}{c}0.259 \\
(0.000)\end{array}$ & $\begin{array}{c}0.263 \\
(0.000)\end{array}$ \\
\hline Abnormal announcement return & $\begin{array}{l}-0.329 \\
(0.783)\end{array}$ & $\begin{array}{l}-0.411 \\
(0.730)\end{array}$ & $\begin{array}{l}-0.291 \\
(0.807)\end{array}$ & $\begin{array}{l}-0.376 \\
(0.753)\end{array}$ & $\begin{array}{l}-0.338 \\
(0.776)\end{array}$ & $\begin{array}{l}-0.344 \\
(0.773)\end{array}$ \\
\hline Prior one-year abnormal return & $\begin{array}{c}0.409 \\
(0.092)\end{array}$ & $\begin{array}{c}0.562 \\
(0.020)\end{array}$ & $\begin{array}{c}0.407 \\
(0.094)\end{array}$ & $\begin{array}{c}0.553 \\
(0.022)\end{array}$ & & $\begin{array}{c}0.546 \\
(0.024)\end{array}$ \\
\hline BM quintile & $\begin{array}{c}0.471 \\
(0.000)\end{array}$ & & $\begin{array}{c}0.464 \\
(0.000)\end{array}$ & & $\begin{array}{c}0.475 \\
(0.000)\end{array}$ & $\begin{array}{c}0.935 \\
(0.000)\end{array}$ \\
\hline CASH quintile & $\begin{array}{c}0.184 \\
(0.003)\end{array}$ & & $\begin{array}{c}0.192 \\
(0.002)\end{array}$ & & $\begin{array}{c}0.194 \\
(0.002)\end{array}$ & $\begin{array}{c}-0.058 \\
(0.791)\end{array}$ \\
\hline LEV quintile & $\begin{array}{c}0.015 \\
(0.827)\end{array}$ & & $\begin{array}{c}0.024 \\
(0.717)\end{array}$ & & $\begin{array}{c}0.022 \\
(0.740)\end{array}$ & $\begin{array}{c}0.207 \\
(0.300)\end{array}$ \\
\hline High BM dummy & & $\begin{array}{c}0.947 \\
(0.000)\end{array}$ & & $\begin{array}{c}0.939 \\
(0.000)\end{array}$ & & \\
\hline High CASH dummy & & $\begin{array}{l}-0.074 \\
(0.736)\end{array}$ & & $\begin{array}{l}-0.044 \\
(0.841)\end{array}$ & & \\
\hline Low LEV dummy & & $\begin{array}{c}0.215 \\
(0.284)\end{array}$ & & $\begin{array}{c}0.188 \\
(0.348)\end{array}$ & & \\
\hline Four-year abnormal return & & & & & & $\begin{array}{c}0.164 \\
(0.031) \\
\end{array}$ \\
\hline
\end{tabular}




\section{Table 7}

\section{Long-Run Abnormal Returns Based on a Five-Factor Model}

This table reports long-run abnormal returns based on the five-factor model. In addition to four factors used in Carhart (1997), we add one more factor, DA factor in the analysis. Excess returns of repurchasing firms are regressed against factors. The five-factor model is specified as follows.

$$
R_{p, t}-R_{f, t}=\alpha+\beta\left(R_{m, t}-R_{f, t}\right)+s S M B_{t}+h H M L_{t}+w W M L_{t}+g G M B_{t}+e_{t}
$$

where $R_{p}$ is the repurchase firm portfolio return, $R_{f}$ is the risk-free rate, $R_{m}$ is the market portfolio return, $S M B$ is the small-firm portfolio return minus big-firm portfolio return, $H M L$ is the high book-to-market portfolio return minus low book-to-market portfolio return, WML is the winner portfolio return minus loser portfolio return, and GMB is the good earnings quality portfolio return minus bad earnings quality portfolio return. In each month from 1983 to 2000 , we form a calendar-time portfolio by including sample firms that have announced repurchase programs in the past 48 months. The portfolio returns are computed by either equal-weighting or log value-weighting individual firm's returns. Months with less than 60 stocks in the portfolio are excluded from the regression. $N$ is the number of months used to run regressions. Numbers in parentheses are $t$-statistics. The rows labeled "Low-High" test the differences between the top and bottom DA quintiles, by taking long on the lowest DA quintile and short on the highest DA quintile, and regress against factors. High- $L$ (High- $H$ ) represents the highest DA quintile with prior one-quarter abnormal return that is below (above) the average prior one-quarter abnormal return of the highest DA quintile firms.

\begin{tabular}{|c|c|c|c|c|c|c|c|c|c|c|c|c|c|c|c|c|}
\hline \multirow{2}{*}{ DA rank } & \multicolumn{8}{|c|}{ Equal-weights } & \multicolumn{8}{|c|}{ Log value-weights } \\
\hline & $\alpha$ & $\beta$ & $s$ & $h$ & $w$ & $g$ & $N$ & Adj. $R^{2}$ & $\alpha$ & $\beta$ & $s$ & $h$ & $w$ & $g$ & $N$ & Adj. $R^{2}$ \\
\hline All & $\begin{array}{c}0.0026 \\
(3.24)\end{array}$ & $\begin{array}{l}0.8596 \\
(43.41)\end{array}$ & $\begin{array}{l}0.3415 \\
(13.59)\end{array}$ & $\begin{array}{c}0.1695 \\
(5.27)\end{array}$ & $\begin{array}{l}-0.2490 \\
(-11.17)\end{array}$ & $\begin{array}{c}-0.2919 \\
(-6.97)\end{array}$ & 216 & $92.58 \%$ & $\begin{array}{c}0.0029 \\
(3.76)\end{array}$ & $\begin{array}{l}0.8723 \\
(45.34)\end{array}$ & $\begin{array}{l}0.2991 \\
(12.25)\end{array}$ & $\begin{array}{c}0.1648 \\
(5.28)\end{array}$ & $\begin{array}{l}-0.2355 \\
(-10.87)\end{array}$ & $\begin{array}{c}-0.3057 \\
(-7.51)\end{array}$ & 216 & $93.02 \%$ \\
\hline Low & $\begin{array}{l}0.0034 \\
(2.92)\end{array}$ & $\begin{array}{l}0.8590 \\
(27.59)\end{array}$ & $\begin{array}{l}0.4357 \\
(12.68)\end{array}$ & $\begin{array}{l}0.1887 \\
(4.00)\end{array}$ & $\begin{array}{c}-0.2606 \\
(-8.05)\end{array}$ & $\begin{array}{c}-0.2190 \\
(-3.85)\end{array}$ & 163 & $87.24 \%$ & $\begin{array}{c}0.0039 \\
(3.35)\end{array}$ & $\begin{array}{l}0.8783 \\
(28.37)\end{array}$ & $\begin{array}{l}0.4112 \\
(12.04)\end{array}$ & $\begin{array}{l}0.1737 \\
(3.70)\end{array}$ & $\begin{array}{c}-0.2614 \\
(-8.12)\end{array}$ & $\begin{array}{c}-0.2417 \\
(-4.27)\end{array}$ & 163 & $87.78 \%$ \\
\hline 2 & $\begin{array}{c}0.0038 \\
(3.87)\end{array}$ & $\begin{array}{l}0.8775 \\
(36.18)\end{array}$ & $\begin{array}{c}0.3058 \\
(9.89)\end{array}$ & $\begin{array}{l}0.1617 \\
(4.03)\end{array}$ & $\begin{array}{c}-0.2463 \\
(-9.09)\end{array}$ & $\begin{array}{c}-0.2990 \\
(-5.84)\end{array}$ & 199 & $90.30 \%$ & $\begin{array}{l}0.0041 \\
(4.20)\end{array}$ & $\begin{array}{l}0.8863 \\
(37.23)\end{array}$ & $\begin{array}{c}0.2658 \\
(8.76)\end{array}$ & $\begin{array}{c}0.1489 \\
(3.78)\end{array}$ & $\begin{array}{c}-0.2316 \\
(-8.71)\end{array}$ & $\begin{array}{c}-0.3151 \\
(-6.27)\end{array}$ & 199 & $0.75 \%$ \\
\hline 3 & $\begin{array}{l}0.0031 \\
(3.47)\end{array}$ & $\begin{array}{l}0.8561 \\
(36.37)\end{array}$ & $\begin{array}{c}0.2386 \\
(8.72)\end{array}$ & $\begin{array}{l}0.2318 \\
(6.44)\end{array}$ & $\begin{array}{c}-0.2269 \\
(-9.40)\end{array}$ & $\begin{array}{c}-0.3010 \\
(-6.74)\end{array}$ & 194 & $90.23 \%$ & $\begin{array}{l}0.0032 \\
(3.66)\end{array}$ & $\begin{array}{l}0.8710 \\
(37.42)\end{array}$ & $\begin{array}{c}0.1966 \\
(7.26)\end{array}$ & $\begin{array}{c}0.2235 \\
(6.28)\end{array}$ & $\begin{array}{c}-0.2137 \\
(-8.96)\end{array}$ & $\begin{array}{c}-0.3180 \\
(-7.20)\end{array}$ & 194 & $90.69 \%$ \\
\hline 4 & $\begin{array}{c}0.0033 \\
(3.21)\end{array}$ & $\begin{array}{l}0.8736 \\
(32.39)\end{array}$ & $\begin{array}{l}0.3496 \\
(11.13)\end{array}$ & $\begin{array}{l}0.2037 \\
(4.86)\end{array}$ & $\begin{array}{c}-0.2480 \\
(-8.92)\end{array}$ & $\begin{array}{l}-0.3437 \\
(-6.72)\end{array}$ & 192 & $88.76 \%$ & $\begin{array}{c}0.0034 \\
(3.42)\end{array}$ & $\begin{array}{c}0.8839 \\
(33.66)\end{array}$ & $\begin{array}{l}0.3093 \\
(10.11)\end{array}$ & $\begin{array}{l}0.2017 \\
(4.94)\end{array}$ & $\begin{array}{c}-0.2343 \\
(-8.66)\end{array}$ & $\begin{array}{c}-0.3528 \\
(-7.08)\end{array}$ & 192 & $89.36 \%$ \\
\hline High & $\begin{array}{l}0.0007 \\
(0.59)\end{array}$ & $\begin{array}{l}0.7981 \\
(24.08)\end{array}$ & $\begin{array}{l}0.4767 \\
(13.38)\end{array}$ & $\begin{array}{l}0.1877 \\
(3.76)\end{array}$ & $\begin{array}{c}-0.3024 \\
(-8.91)\end{array}$ & $\begin{array}{c}-0.1973 \\
(-3.32)\end{array}$ & 162 & $84.82 \%$ & $\begin{array}{l}0.0010 \\
(0.83)\end{array}$ & $\begin{array}{l}0.8152 \\
(25.58)\end{array}$ & $\begin{array}{l}0.4491 \\
(13.11)\end{array}$ & $\begin{array}{l}0.1734 \\
(3.62)\end{array}$ & $\begin{array}{c}-0.2938 \\
(-9.00)\end{array}$ & $\begin{array}{c}-0.2308 \\
(-4.04)\end{array}$ & 162 & $86.04 \%$ \\
\hline Low - High & $\begin{array}{l}0.0032 \\
(2.87)\end{array}$ & $\begin{array}{l}0.0462 \\
(1.57)\end{array}$ & $\begin{array}{c}-0.0332 \\
(-0.95)\end{array}$ & $\begin{array}{c}0.0138 \\
(0.30)\end{array}$ & $\begin{array}{c}0.0325 \\
(1.07)\end{array}$ & $\begin{array}{c}-0.0031 \\
(-0.06)\end{array}$ & 199 & $7.17 \%$ & $\begin{array}{l}0.0033 \\
(3.00)\end{array}$ & $\begin{array}{l}0.0515 \\
(1.81)\end{array}$ & $\begin{array}{c}-0.0318 \\
(-0.94)\end{array}$ & $\begin{array}{l}0.0128 \\
(0.29)\end{array}$ & $\begin{array}{l}0.0240 \\
(0.81)\end{array}$ & $\begin{array}{l}0.0075 \\
(0.14)\end{array}$ & 199 & $7.87 \%$ \\
\hline High-L & $\begin{array}{c}-0.0005 \\
(-0.27)\end{array}$ & $\begin{array}{l}0.8200 \\
(16.77)\end{array}$ & $\begin{array}{c}0.5614 \\
(11.41)\end{array}$ & $\begin{array}{l}0.1947 \\
(2.88)\end{array}$ & $\begin{array}{c}-0.3660 \\
(-8.04)\end{array}$ & $\begin{array}{c}-0.1270 \\
(-1.58)\end{array}$ & 122 & $80.20 \%$ & $\begin{array}{c}-0.0002 \\
(-0.09)\end{array}$ & $\begin{array}{l}0.8449 \\
(17.86)\end{array}$ & $\begin{array}{l}0.5466 \\
(11.48)\end{array}$ & $\begin{array}{l}0.1900 \\
(2.90)\end{array}$ & $\begin{array}{c}-0.3605 \\
(-8.19)\end{array}$ & $\begin{array}{c}-0.1599 \\
(-2.06)\end{array}$ & 122 & $81.69 \%$ \\
\hline High-H & $\begin{array}{l}0.0039 \\
(2.77)\end{array}$ & $\begin{array}{l}0.7223 \\
(18.85)\end{array}$ & $\begin{array}{l}0.4299 \\
(11.20)\end{array}$ & $\begin{array}{l}0.2198 \\
(4.06)\end{array}$ & $\begin{array}{c}-0.2676 \\
(-7.48)\end{array}$ & $\begin{array}{c}-0.1547 \\
(-2.41)\end{array}$ & 124 & $82.72 \%$ & $\begin{array}{l}0.0041 \\
(3.04)\end{array}$ & $\begin{array}{l}0.7357 \\
(20.06)\end{array}$ & $\begin{array}{l}0.4048 \\
(11.02)\end{array}$ & $\begin{array}{l}0.2133 \\
(4.12)\end{array}$ & $\begin{array}{c}-0.2593 \\
(-7.57)\end{array}$ & $\begin{array}{c}-0.1817 \\
(-2.96)\end{array}$ & 124 & $84.05 \%$ \\
\hline
\end{tabular}


Table 8

\section{Cash and Leverage Ranked by Discretionary Accruals}

This table presents cash and leverage sorted by discretionary accruals (DA) quintiles. Cash is defined as cash plus short-term investments over total assets and is adjusted for industry median. Leverage is based on the ratio of the total debt to total assets and is adjusted for industry median. Year -1 is the fiscal year prior to the repurchase announcement while Year 1 is the fiscal year which contains the repurchase announcement. $N$ is the number of firms in each group with available cash and leverage. Numbers in parentheses are $t$-statistics. The row labeled "Low-High" tests the difference between the top and bottom DA quintiles. High- $L$ (High- $H$ ) represents the highest DA quintile with prior one-quarter abnormal return that is below (above) the average prior one-quarter abnormal return of the highest DA quintile firms.

\begin{tabular}{|c|c|c|c|c|c|c|c|}
\hline \multirow{2}{*}{ DA rank } & \multirow{2}{*}{$\mathrm{N}$} & \multicolumn{3}{|c|}{ Cash } & \multicolumn{3}{|c|}{ Leverage } \\
\hline & & Year -1 & Year 1 & Year -1 to 1 & Year -1 & Year 1 & Year -1 to 1 \\
\hline Low & 994 & $\begin{array}{l}0.0905 \\
(16.47)\end{array}$ & $\begin{array}{l}0.0870 \\
(15.80)\end{array}$ & $\begin{array}{c}-0.0035 \\
(-0.98)\end{array}$ & $\begin{array}{l}0.0149 \\
(2.25)\end{array}$ & $\begin{array}{c}0.0128 \\
(1.86)\end{array}$ & $\begin{array}{c}-0.0022 \\
(-0.56)\end{array}$ \\
\hline 2 & 1754 & $\begin{array}{l}0.0628 \\
(16.31)\end{array}$ & $\begin{array}{l}0.0535 \\
(14.47)\end{array}$ & $\begin{array}{c}-0.0093 \\
(-4.11)\end{array}$ & $\begin{array}{c}-0.0141 \\
(-3.04)\end{array}$ & $\begin{array}{c}-0.0122 \\
(-2.61)\end{array}$ & $\begin{array}{c}0.0019 \\
(0.86)\end{array}$ \\
\hline 3 & 1899 & $\begin{array}{l}0.0395 \\
(10.93)\end{array}$ & $\begin{array}{l}0.0336 \\
(10.12)\end{array}$ & $\begin{array}{c}-0.0059 \\
(-2.99)\end{array}$ & $\begin{array}{c}-0.0260 \\
(-6.27)\end{array}$ & $\begin{array}{c}-0.0217 \\
(-5.24)\end{array}$ & $\begin{array}{c}0.0044 \\
(2.15)\end{array}$ \\
\hline 4 & 1719 & $\begin{array}{l}0.0403 \\
(10.48)\end{array}$ & $\begin{array}{c}0.0348 \\
(9.22)\end{array}$ & $\begin{array}{c}-0.0055 \\
(-2.46)\end{array}$ & $\begin{array}{c}-0.0377 \\
(-8.16)\end{array}$ & $\begin{array}{c}-0.0341 \\
(-7.46)\end{array}$ & $\begin{array}{c}0.0036 \\
(1.60)\end{array}$ \\
\hline High & 1168 & $\begin{array}{l}0.0337 \\
(7.39)\end{array}$ & $\begin{array}{c}0.0326 \\
(7.07)\end{array}$ & $\begin{array}{c}-0.0011 \\
(-0.36)\end{array}$ & $\begin{array}{c}-0.0258 \\
(-4.20)\end{array}$ & $\begin{array}{c}-0.0273 \\
(-4.61)\end{array}$ & $\begin{array}{c}-0.0016 \\
(-0.49)\end{array}$ \\
\hline Low - High & & $\begin{array}{c}0.0567 \\
(7.95)\end{array}$ & $\begin{array}{c}0.0544 \\
(7.57)\end{array}$ & $\begin{array}{c}-0.0023 \\
(-0.50)\end{array}$ & $\begin{array}{l}0.0407 \\
(4.50)\end{array}$ & $\begin{array}{c}0.0401 \\
(4.42)\end{array}$ & $\begin{array}{c}-0.0006 \\
(-0.12)\end{array}$ \\
\hline High-L & 583 & $\begin{array}{c}0.0498 \\
(7.19)\end{array}$ & $\begin{array}{c}0.0422 \\
(6.22)\end{array}$ & $\begin{array}{c}-0.0076 \\
(-1.63)\end{array}$ & $\begin{array}{c}-0.0348 \\
(-4.11)\end{array}$ & $\begin{array}{c}-0.0312 \\
(-3.75)\end{array}$ & $\begin{array}{c}0.0036 \\
(0.78)\end{array}$ \\
\hline High-H & 585 & $\begin{array}{c}0.0178 \\
(3.02)\end{array}$ & $\begin{array}{c}0.0231 \\
(3.70)\end{array}$ & $\begin{array}{l}0.0053 \\
(1.31)\end{array}$ & $\begin{array}{c}-0.0168 \\
(-1.89)\end{array}$ & $\begin{array}{c}-0.0235 \\
(-2.77)\end{array}$ & $\begin{array}{c}-0.0067 \\
(-1.51)\end{array}$ \\
\hline
\end{tabular}




\section{Table 9 \\ Cross-Sectional Regressions of Long-Run Abnormal Returns}

This table reports cross-sectional regression results of long-run abnormal returns. The dependent variable is four-year abnormal stock return. DA quintile (1 is the smallest) is the quintile ranking of DA obtained from the Jones (1991) model. High DA dummy is l for the top DA quintile, and 0 elsewhere. High-L dummy is 1 if a sample firm belongs to the top DA quintile and its one-quarter abnormal return prior to repurchase announcement is below the average prior one-quarter abnormal return of the highest DA quintile firms, and 0 elsewhere. Size decile (1 being the smallest) is based on the market value of equity at the month-end prior to the repurchase announcement. $B / M$ quintile (1 being the lowest) is based on the ratio of the book equity value at the previous fiscal year-end to total market value at month-end prior to the announcement. CASH quintile is based on the industry median-adjusted cash plus short-term investment over total assets. LEV quintile is based on the industry median-adjusted ratio of the total debt to total assets at the fiscal year-end prior to the announcement. High BM dummy is 1 for the top BM quintile, and 0 elsewhere. High CASH dummy is 1 for the top CASH quintile, and 0 elsewhere. Low LEV dummy is 1 for the bottom LEV quintile, and 0 elsewhere. \% shares announced is the percentage of announced repurchase shares relative to total outstanding shares at the month-end prior to the announcement. Prior one-year abnormal return is the prior one year buy-and-hold returns compounded from 252 days before (or the listing date) up to three days before the announcement for repurchasing firms minus the compounded return of the matching firms over the same period. Actual buyback is the actual buyback amount divided by average market value of equity. High-DA dummy is used (except for model 7) for the interactive dummy with Actual buyback. Year dummy variables are included, but not reported. $\quad$ Numbers in parentheses are White (1980) heteroskedasticity-adjusted $t$-statistics.

\begin{tabular}{|c|c|c|c|c|c|c|c|}
\hline Model & 1 & 2 & 3 & 4 & 5 & 6 & 7 \\
\hline Intercept & $\begin{array}{c}0.0725 \\
(0.74)\end{array}$ & $\begin{array}{l}0.2350 \\
(3.45)\end{array}$ & $\begin{array}{l}0.1017 \\
(1.03)\end{array}$ & $\begin{array}{c}0.2611 \\
(3.79)\end{array}$ & $\begin{array}{c}-0.0213 \\
(0.24)\end{array}$ & $\begin{array}{c}0.1535 \\
(2.62)\end{array}$ & $\begin{array}{c}0.1598 \\
(2.77)\end{array}$ \\
\hline DA quintile & $\begin{array}{c}-0.0334 \\
(-2.87)\end{array}$ & $\begin{array}{c}-0.0315 \\
(-2.72)\end{array}$ & $\begin{array}{c}-0.0445 \\
(-3.52)\end{array}$ & $\begin{array}{c}-0.0425 \\
(-3.37)\end{array}$ & & & \\
\hline High DA dummy & & & & & $\begin{array}{c}-0.1076 \\
(-2.05)\end{array}$ & $\begin{array}{c}-0.1029 \\
(-1.96)\end{array}$ & \\
\hline High-L dummy & & & & & & & $\begin{array}{c}-0.2301 \\
(-3.25)\end{array}$ \\
\hline Size decile & $\begin{array}{c}0.0165 \\
(3.02)\end{array}$ & $\begin{array}{c}0.0163 \\
(3.08)\end{array}$ & $\begin{array}{c}0.0174 \\
(3.17)\end{array}$ & $\begin{array}{c}0.0171 \\
(3.22)\end{array}$ & $\begin{array}{c}0.0159 \\
(2.87)\end{array}$ & $\begin{array}{c}0.0161 \\
(3.00)\end{array}$ & $\begin{array}{c}0.0152 \\
(2.85)\end{array}$ \\
\hline BM quintile & $\begin{array}{c}0.0083 \\
(0.70)\end{array}$ & & $\begin{array}{c}0.0082 \\
(0.69)\end{array}$ & & $\begin{array}{c}0.0058 \\
(0.49)\end{array}$ & & \\
\hline CASH quintile & $\begin{array}{l}0.0056 \\
(0.50)\end{array}$ & & $\begin{array}{c}0.0056 \\
(0.51)\end{array}$ & & $\begin{array}{l}0.0090 \\
(0.81)\end{array}$ & & \\
\hline LEV quintile & $\begin{array}{c}0.0425 \\
(3.61)\end{array}$ & & $\begin{array}{l}0.0417 \\
(3.54)\end{array}$ & & $\begin{array}{c}0.0450 \\
(3.84)\end{array}$ & & \\
\hline High BM dummy & & $\begin{array}{c}0.0180 \\
(0.39)\end{array}$ & & $\begin{array}{c}0.0161 \\
(0.35)\end{array}$ & & $\begin{array}{c}0.0138 \\
(0.30)\end{array}$ & $\begin{array}{c}0.0102 \\
(0.22)\end{array}$ \\
\hline High CASH dummy & & $\begin{array}{c}0.0750 \\
(1.89)\end{array}$ & & $\begin{array}{c}0.0738 \\
(1.86)\end{array}$ & & $\begin{array}{l}0.0855 \\
(2.16)\end{array}$ & $\begin{array}{c}0.0836 \\
(2.12)\end{array}$ \\
\hline Low LEV dummy & & $\begin{array}{c}-0.1256 \\
(-3.60)\end{array}$ & & $\begin{array}{c}-0.1223 \\
(-3.50)\end{array}$ & & $\begin{array}{c}-0.1308 \\
(-3.76)\end{array}$ & $\begin{array}{c}-0.1307 \\
(-3.76)\end{array}$ \\
\hline$\%$ shares announced & $\begin{array}{l}0.3837 \\
(1.83)\end{array}$ & $\begin{array}{l}0.4017 \\
(1.92)\end{array}$ & $\begin{array}{c}0.3796 \\
(1.81)\end{array}$ & $\begin{array}{c}0.3979 \\
(1.90)\end{array}$ & $\begin{array}{c}0.3842 \\
(1.82)\end{array}$ & $\begin{array}{l}0.4007 \\
(1.90)\end{array}$ & $\begin{array}{r}0.3967 \\
(1.88)\end{array}$ \\
\hline Prior one-year abnormal return & $\begin{array}{c}0.0194 \\
(0.46)\end{array}$ & $\begin{array}{c}0.0238 \\
(0.57)\end{array}$ & $\begin{array}{c}0.0224 \\
(0.53)\end{array}$ & $\begin{array}{c}0.0269 \\
(0.65)\end{array}$ & $\begin{array}{c}0.0257 \\
(0.61)\end{array}$ & $\begin{array}{c}0.0290 \\
(0.69)\end{array}$ & $\begin{array}{c}0.0114 \\
(0.26)\end{array}$ \\
\hline Actual buyback & $\begin{array}{c}0.4762 \\
(1.99)\end{array}$ & $\begin{array}{l}0.4891 \\
(2.06)\end{array}$ & $\begin{array}{l}0.3326 \\
(1.36)\end{array}$ & $\begin{array}{c}0.3485 \\
(1.44)\end{array}$ & $\begin{array}{c}0.3365 \\
(1.36)\end{array}$ & $\begin{array}{l}0.3521 \\
(1.43)\end{array}$ & $\begin{array}{c}0.3789 \\
(1.57)\end{array}$ \\
\hline Actual buyback $\times$ High DA (or High-L) dummy & & & $\begin{array}{l}1.2118 \\
(2.00)\end{array}$ & $\begin{array}{c}1.1884 \\
(1.96) \\
\end{array}$ & $\begin{array}{l}1.2443 \\
(1.75) \\
\end{array}$ & $\begin{array}{c}1.2146 \\
(1.71)\end{array}$ & $\begin{array}{l}1.8060 \\
(1.95)\end{array}$ \\
\hline
\end{tabular}




\section{Figure 1}

\section{Operating Performance based on Earnings Components around Repurchase Announcement}

This figure plots operating performance based on earnings components for the Highest (DA5) and Lowest (DA1) DA quintiles. Earnings are operating income after depreciation. Accruals are defined as changes in non-cash current assets, minus changes in current liabilities (excluding short-term debt and taxes payable) minus depreciation. Cash flows are earnings less accruals. Earnings, accruals, cash flows and sales are scaled by average total assets. These graphs plot performance from year -5 to year -1 prior to repurchase announcement, where year -1 is the fiscal year prior to the repurchase announcement. High- $L(H i g h-H)$ plot evidence where the Highest DA quintile is sub-divided into two groups by whether the prior one-quarter abnormal return is below (High-L) or above (High-H) the average for all firms in the highest DA quintile.

Panel A: Low DA vs. High DA

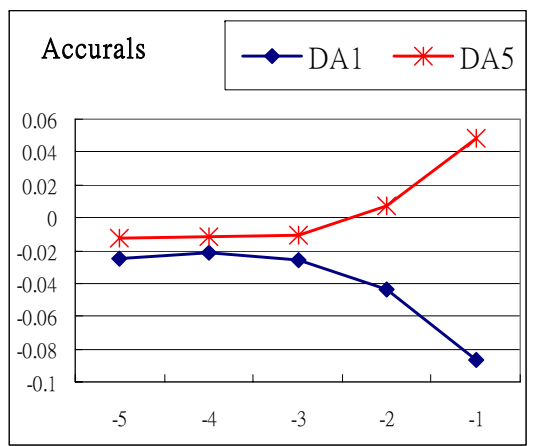

Panel B. High-L vs. High-H

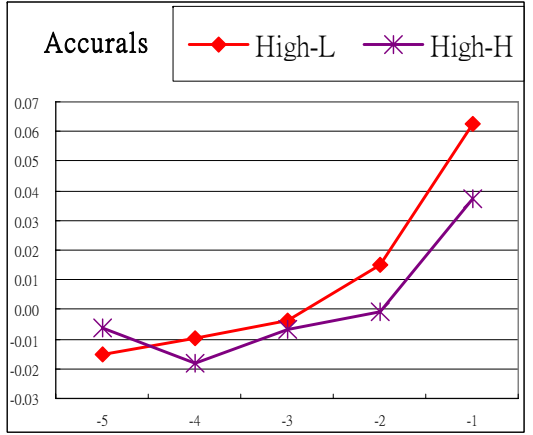

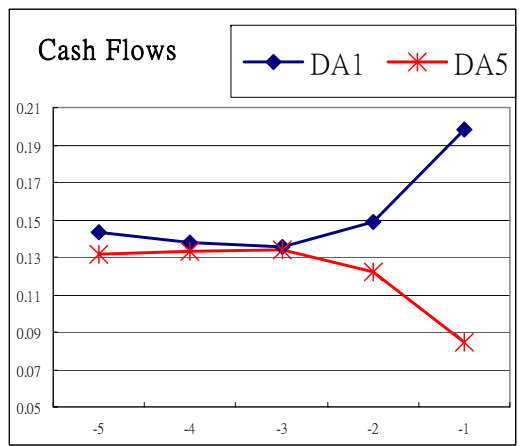

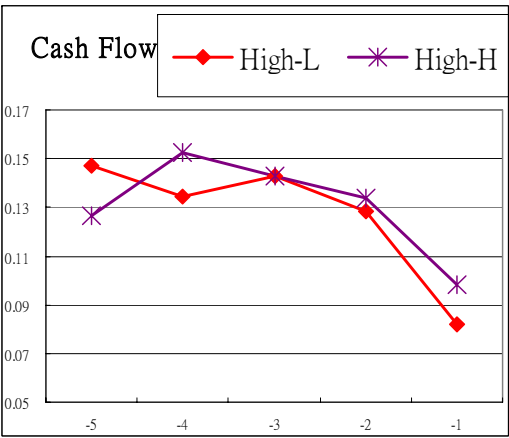

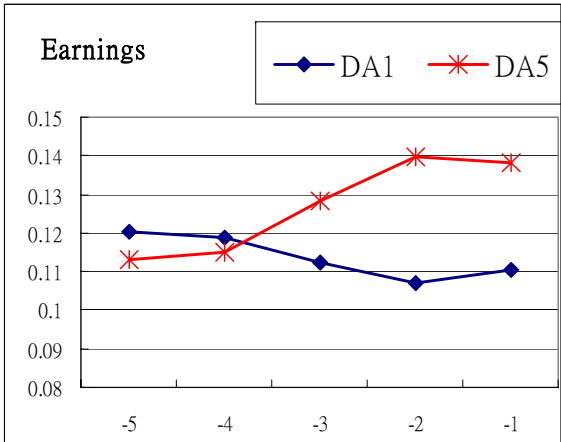
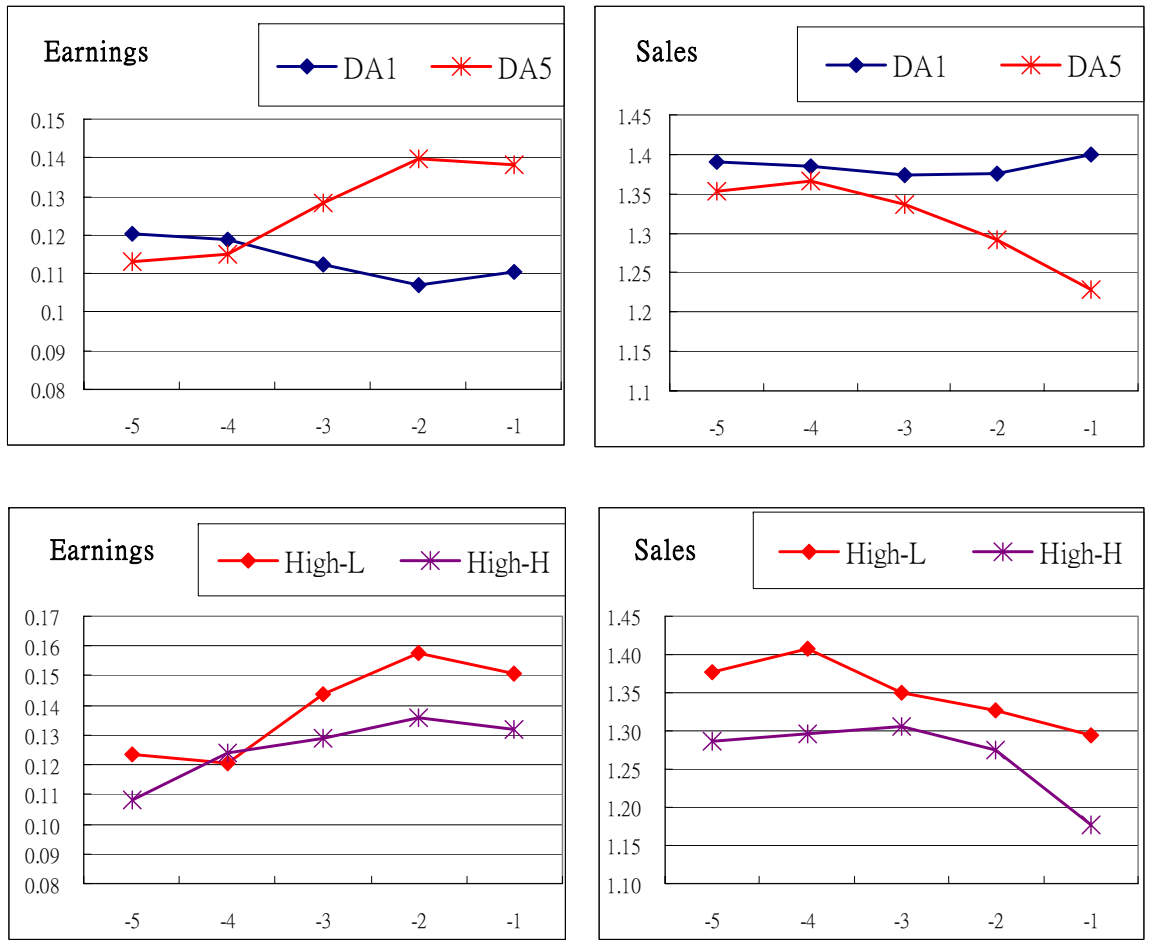